\title{
Re-evaluation of the Cancridae Latreille, 1802 (Decapoda: Brachyura) including three new genera and three new species
}

\author{
Carrie E. Schweitzer \& Rodney M. Feldmann \\ Department of Geology, Kent State University, Kent, Ohio 44242 U.S.A. E-mail: cschweitzer@Stark.kent. \\ edu and rfeldman@kent.edu
}

Keywords: Decapoda, Brachyura, Cancridae, Tertiary, paleobiogeography, Tethys

\begin{abstract}
New fossils referrable to the Cancridae Latreille, 1802 extend the known stratigraphíc range of the family into the middle Eocene and the geographic range into South America. Each genus within the family has been reevaluated within the context of the new material. A suite of diagnostic characters for each cancrid genus makes it possible to assign both extant and fossil specimens to genera and the two cancrid subfamilies, the Cancrinae Latreille, 1802, and Lobocarcininae Beurlen, 1930, based solely upon dorsal carapace morphology. Cheliped morphology is useful in assigning genera to the family but is significantly less useful at the subfamily and generic level. Each of the four subgenera sensu Nations (1975), Cancer Linnaeus, 1758, Glebocarcinus Nations, 1975, Metacarcinus A. Milne Edwards, 1862, and Romaleon Gistl, 1848, are elevated to full generic status. Additionally, three new genera and three new species accommodate the new, as well as some previously described taxa, and include Anatolikos new genus, Anisospinos berglindi new genus and species, and Notocarcinus sulcatus new genus and species and several new combinations. Recognition of new genera and reassignment of several species within the Cancrinae indicates that that subfamily may have arisen in the southern hemisphere, contrary to the previous interpretation of the subfamily as a primarily North Pacific or Tethyan group. The Lobocarcininae was primarily a Tethyan group.
\end{abstract}

\section{Contents}

Introduction

Systematic Paleontology

Family Cancrídae Latreille, 1802

Subfamily Cancrinae, Latreille, 1802

Cancer sensu stricto Linnaeus, 1758

Anatolikos new genus

Anisospinos new genus
Metacarcinus A. Milne Edwards, 1862

Metacarcinus goederti new species

Notocarcinus new genus

Notocarcinus sulcatus new specíes

Platepistoma Rathbun, 1906

Romaleon Gistl, 1848

Subfamily Lobocarcininae Beurlen, 1930

Lobocarcinus Reuss, 1867

Miocyclus Müller, 1979

Tasadia Mũller in Janssen and Müller, 1984

Discussion

Acknowledgements

References

Appendix A

Appendix B

\section{Introduction}

The Cancridae Latreille, 1802, has heretofore consisted of two extant genera known from the fossil record, Cancer sensu lato and Platepistoma Rathbun, 1906, and several exclusively fossil genera including Lobocarcinus Reuss, 1867; Microdium Reuss, 1867; Miocyclus, Müller, 1979; Parapirimela Van Straelen, 1937; and Tasadia Müller in Janssen and Müller, 1984. Cancer sensu lato was subdivided into four subgenera by Nations (1975) including Cancer, Glebocarcinus, Metacarcinus, and Romaleon. All of these genera and subgenera were defined primarily upon the number, size, and shape of the frontal spines; the number, size, ornament, and shape of the anterolateral spines; the ornament of the posterolateral margin; the shape, development, and ornament of carapace regions, and the shape and ornament of the chelae. 
The discovery of new fossil material from Alaska and Washington, USA, and southern Argentina requires a re-evaluation of the family. Within this work, the four subgenera referred to Cancer sensu lato are elevated to full generic status. Examination of all species referred to the Cancridae necessitates the transfer of several species to other genera and results in recognition of three new genera to accommodate new material as well as some previously described fossil and extant species (Appendix A). New genera include Anatolikos, Anisospinos, and Notocarcinus. Neither Parapirimela nor Branchiolambrus are verifiable members of the Cancridae as discussed below. Additionally, the morphology of the chelae has been found to be useful in assigning taxa to the family based upon the overall shape and ornamentation. However, chelae are significantly less useful in assigning taxa to genera, be: cause of the variability in chela morphology.

The evolutionary and biogeographic history of the group must be reinterpreted within the context of the new fossil material. The discovery of Notocarcinus sulcatus new genus and species from middle Eocene rocks of Argentina constitutes the earliest known occurrence of the Cancrinae and also the first known fossil occurrence of the Cancridae in South America. Anisospinos berglundi is the only other Eocene occurrence known, reported from late Eocene rocks of the western Washington. It is possible that the Cancrinae arose in the southern hemisphere and subsequently dispersed northward to the North Pacific and North Atlantic Oceans, where it is currently well-established. The Cancrinae was previously believed to have had a primarily North Pacific (Nations, $19 \nmid 5$, 1979; Carvacho, 1989) or Tethyan (Newman, 1991) distribution. Most of the genera assigned to the Cancrinae in this report, including Anatolikos new genus, Anisospinos new genus, Cancer sensu stricto, Platepistoma, and Romaleon, apparently originated in the North Pacific region based upon known occurrences. Assignment of the European genera Miocyclus and Tasadia to the Lobocarcinininae supports the primarily Tethyan distribution of that subfamily.

\section{Systematic Paleontology}

Order Decapoda Latreille, 1802

Infraorder Brachyura Latreille, 1802

Section Heterotremata Guinot, 1977

Family Cancridae Latreille, 1802

Diagnosis. - Carapace wider than long; anterior margin with four to six spines, with odd or even number usually diagnostic of subfamilies; anterolateral margin with numerous spines, usually more than eight; posterolateral margin entire, rimmed or spined; carapace regions ranging from indistinct to extremely well-defined; carapace ornament ranging from smooth to coarsely granular to spined; chelae typically with keels, spines or granules on manus and fingers. Sternum narrow, triangular in shape; sternites 3-5 often fused in males. "Antennules folded lengthwise. Antennal flagella present, short, more or less hairy. Third maxillipeds usually overlapping endostome" (Rathbun, 1930, p. 176). "Carapace broadly oval or hexagonal. Last pair of legs not adapted for swimming" (Williams, 1984, p. 351).

Remarks. - This diagnosis (and all the diagnoses to follow) focus on characters that are typically preserved in fossils and that are therefore most useful to paleontologists. The main feature uniting the family is a high degree of carapace ornamentation, especially the frontal, anterolateral, and posterolateral spines and/or rims. Additionally, members of the family possess mani of the first pereiopods that are equal or subequal and ornamented with smooth, granular, or spined keels. A key to all genera herein included within the family (Appendix B; Fig. 1), employs these characteristics to distinguish taxa. Müller (1984) placed the genus Microdium, within the Cancridae, and suggested that it may be closely allied to or synonymous with Cancer $s . l$. However, the holotype for the sole species, M. nodulosum, has been lost (Müller, 1984), so confirmation of the status of that genus is impossible. According to Müller (1984, p. 77), it is clear that the taxon does belong within the Cancridae, but because of the lost type, the genus is not included in the key.

Van Straelen (1937) and Glaessner (1969) placed 


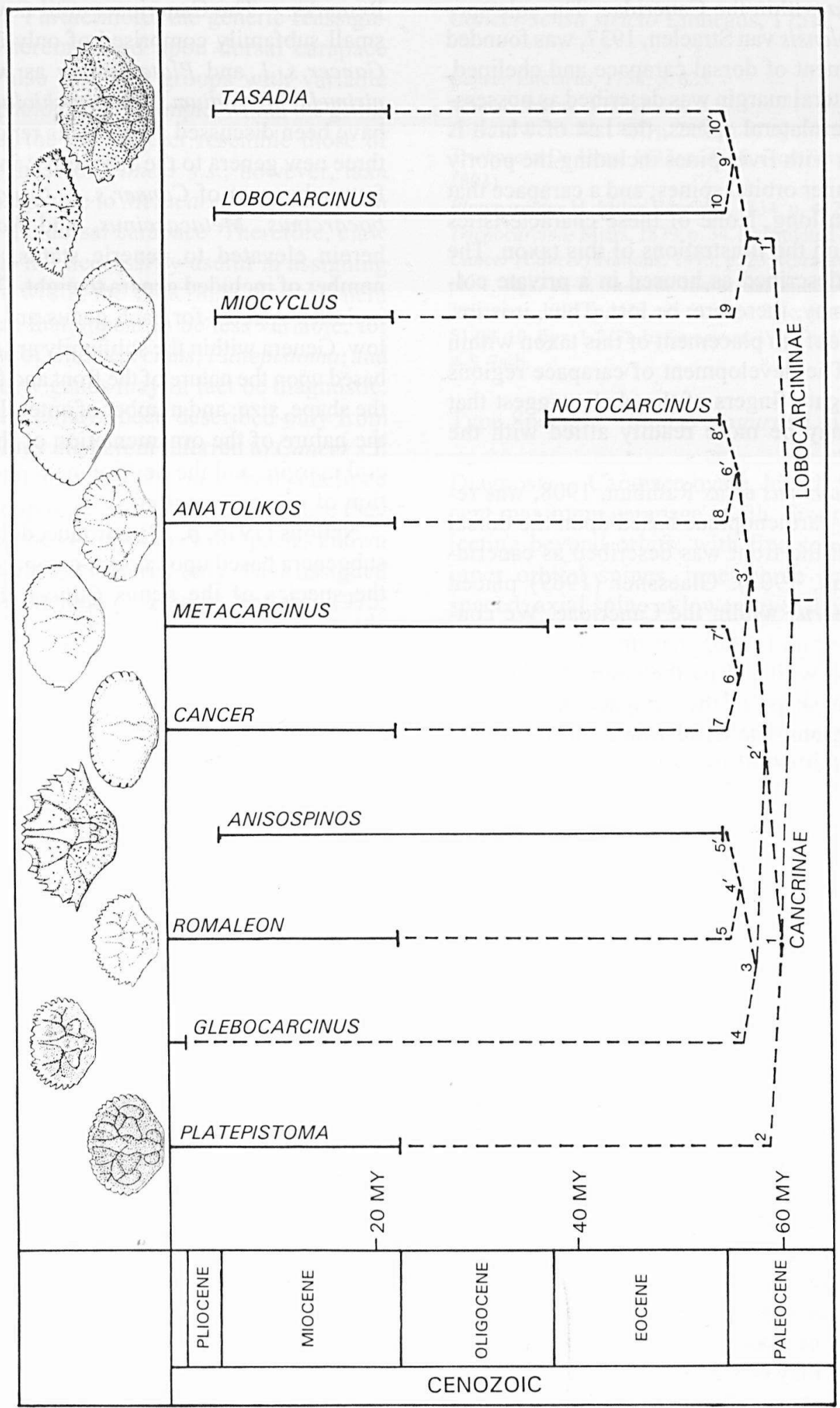

Fig. 1. Illustrated key to the subfamilies and genera of the Cancridae showing the geologic range of each genus. The branching structure of the key does not reflect phylogeny; each node represents a couplet in the dichotomous key (Appendix B). 
Parapirimela within the Cancrìdae. The sole species, $P$, angolensis van Straelen, 1937, was founded upon a fragment of dorsal carapace and cheliped. The anterolateral margin was described as possessing four anterolateral spines, the last of which is bifid; a front with five spines including the poorly developed inner orbital spines; and a carapace that is wider than long. None of these characteristics can be seen on the illustrations of this taxon. The holotype is described as housed in a private collection and may, therefore, be lost. Thus, it is impossible to confirm placement of this taxon within the family. The development of carapace regions and the elongate fingers of the chela suggest that this taxon may be more readily allied with the Xanthidae.

Branchiolambrus altus Rathbun, 1908, was referred to the Parthenopidae based upon the dorsal carapace, but the front was described as cancridlike (Rathbun, 1908). Glaessner (1969) placed Branchiolambrus within the Cancridae. We concur with Rathbun (1908) that this genus is most closely allied with the parthenopids based upon the triangular shape of the carapace, the inflated branchial regions, the trifid front, and the small, circular orbits.

\section{Subfamily Cancrinae Latreille, 1802}

Included genera. - Anatolikos new genus; Anissospinos new genus; Cancer sensu stricto Linnaeus, 1758; Glebocarcinus Nations, 1975; Metacarcinus A. Millne Edwards, 1862; Notocarcinus new genus; Platepistoma Rathbun, 1906; Romaleon Gistl, 1848.

Diagnosis. - Carapace wider than long; front with five spines including inner orbital spines, axial spine may be at lower level than other spines; orbits with two fissures; anterolateral margin with numerous spines, spines fissured or separated to bases; posterolateral margin entire, rimmed, or with one or two small spines; posterior margin entire or rimmed; carapace regions variable, may be distinct or indistinct, may be ornamented with granules or tubercles or may be smooth; chelae with several keels on mani, keels may be smooth, granular, or spined; mani of chelae ranging from short and high to long and slender; fingers of chelae ranging from short and high to long and slender.
Remarks. - The Cancrinae, until now, has been a small subfamily comprised of only a few genera, Cancer $s . l_{*}$ and Platepistoma as well as Parapirimela, Microdium, and Branchiolambrus, which have been discussed above. This report introduces three new genera to the subfamily; in addition, the four subgenera of Cancer s. $l$, Cancer s. s., Glebocarcinus, Metacarcinus, and Romaleon, are herein elevated to generic status, bringing the number of included genera to eight. Diagnoses and included species for each genus are provided below. Genera within the subfamily are distinguished based upon the nature of the front and frontal spines; the shape, size, and number of anterolateral spines; the nature of the ornamentation of the posterolateral margin; and the development and ornamentation of carapace regions.

Nations (1975, p. 22) introduced the use of four subgenera based upon dorsal carapace features for the species of the genus Cancer, believing the characters of the carapace to be more conservative evolutionarily than cheliped characters. The distinct differences in the nature of the front, the anterolateral spines, the posterolateral margins, and the development and ornamentation of dorsal carapace are sufficiently distinct to justify elevation of the subgenera to generic status. In the present work, species assigned to Cancer $s . l$. were placed into genera based upon characteristics of the dorsal carapace only. This has resulted in some reassignments of taxa compared with those of Nations (1975).

Even though Nations (1975) primarily used dorsal carapace morphology to define the four subgenera, he employed the morphology of the claws and fingers to erect several new species and to assign them to subgenera. Important features of the chelae include the number of keels on the outer surface of the manus; the ornamentation of the keels; the spinosity of the upper margin of the manus; the spinosity of the upper margin of the movable finger; and the number, size, and color of the denticles on the occlusal surfaces of the fixed and movable fingers. However, the subgenera as Nations (1975) defined them contain chelae of extremely variable morphology, indicating that the morphology of the chelipeds is insufficient to permit confident generic placement of the species formerly referred 
to Cancer s. $l$. Furthermore, the generic reassignments made herein based upon dorsal carapace morphology also result in groups with variable cheliped morphology. For example, within the genus Metacarcinus, the mani either resemble those of Romaleon or those of Cancer s.s.; however, taxa are readily assignable to Metacarcinus based upon the nature of the dorsal carapace. Therefore, claw morphology is not necessarily useful in assigning taxa to genera within the Cancrinae. Some genera do have chelae that appear to be less variable; for example, those of Glebocarcinus, Platepistoma, and Anisospinos new genus may in fact be diagnostic.

Those taxa that have been described only from claw morphology are herein referred to Cancer $s . l$. The validity of taxa known only from cheliped fragments is impossible to determine because they may or may not be synonymous with species known from dorsal carapace material only. Taxa assigned to Cancer s. l. include C. allisoni Nations, 1975; C. chaneyi Nations, 1975; C. coosensis Nations, 1975; C. durhami Nations, 1975; C. garthi Nations, 1975; C. marri Nations, 1975; C. styriacus Bittner, 1883; and C. yanceyi Nations, 1975. Cancerites molassicus Quenstedt, 1867 is known only from a portion of a finger, and is removed from Cancer s. $l$., concurring with Collins and Fraaye (1991).

Of the eight genera referred to the Cancrinae, two, Anisospinos n. gen. and Notocarcinus n. gen. are known exclusively from the fossil record, and members of these two genera document extension of the range of the subfamily into the Eocene. Notocarcinus sulcatus $\mathrm{n}$. $\mathrm{sp}$. is known from the middle Eocene of Argentina and Anisospinos berglundi $\mathrm{n}$. sp. has been collected from late Eocene rocks of the Olympic Peninsula, Washington. Each of the other genera, except Glebocarcinus, has a fossil record extending into the Miocene. Verifiable occurrences of Glebocarcinus are known only from the Recent.

\section{Cancer sensu stricto Linneaus, 1758}

Cancer Linnaeus, 1758, p. 625.

Alpheus Weber, 1795, p. 91.

Pagurus Berthold, 1827, p. 255, (non Pagurus Fabricius, 1775).

Trichocera De Haan, 1833, p. 4, 16, (non Trichocera Meigen, 1803).

Platycarcinus H. Milne Edwards, 1834, p. 412.

Trichocarcinus Miers, 1879, p. 34, (substituted for Trichocera). Cancer (Cancer) Nations, 1975, p. 23; Karasawa, 1990, p. 11 , pl. 1, figs. 2a-d, 3a-d, 8, 16a-b; Sakumoto, Karasawa, and Takayasu, 1992, p. 448, pl. 61, figs. 3a-c; Karasawa, 1993, p. 51, pl. 10, figs. 1-2, 7a-b; Karasawa, 1997, p. 47, pl. 10, figs. 1 , 4-5, 7a-b.

Type Species. - Cancer pagurus Linnaeus, 1758.

Diagnosis. - Carapace ovate, length 58 to 66 percent maximum carapace width. Front weakly projecting beyond orbits; with five spines including inner orbital spines, inner three spines closely spaced; axial spine at lower level than other frontal spines, frontal region axially sulcate, sulcus extending posteriorly from position of medial frontal spine. Fronto-orbital width from 22 to 29 percent maximum carapace width; orbits shallow, small, with two fissures, directed forward. Anterolateral margin very tightly curved posteriorly; nine anterolateral spines, separated by fissures, typically truncated distally but occasionally produced into sharp spines posteriorly, margins of spines entire, granular or serrate. Posterolateral margin weakly concave, rimmed, typically with one spine. Posterior margin rimmed, convex. Regions usually indistinct, best developed axially; smooth or finely granular.

Manus of chelipeds coarsely granular or smooth, short; usually with three or four granular ridges on outer surface; upper margin keeled, sometimes with small sharp or blunt spines; lower margin keeled; distal margin typically extending at approximately 90 degree angle to upper margin. Movable finger short; upper surface granular or smooth, occlusal surface with large, blunt denticles. Fixed finger short, with central keel or smooth, occlusal surface with large, blunt denticles.

Remarks. - Species of Cancer $s . s$. are united in possessing anterolateral spines that are deeply fissured, a weakly produced front, and one posterolat- 
eral spine. The chela of members of the genus is typically short with short fingers and granular or smooth keels.

Cancer plebejus was referred to the subgenus Metacarcinus by Nations (1975). It is here placed within Cancer $s . s$. based upon its possession of fissured spines and a weakly produced front with small, forward-directed orbits. Cancer borealis was placed within Metacarcinus by Nations (1975); it is here placed within Cancer $s . s$. based upon possession of fissured anterolateral spines and a weakly produced front.

Packard (1900) reported Cancer proavitus from Miocene deposits of the east coast of North America. It possesses a linear row of tubercles on the axial regions and tubercles on the hepatic regions, ornamentation not seen in cancrids. Furthermore, the material exhibits an epibranchial ridge that is ornamented with several tubercles. These features suggest that the specimen may be referrable to the Portunidae, and in fact, the morphology of the sternites is typical of portunid taxa. Cancer proavitus is therefore removed from the Cancridae and placed within the Portunidae; unfortunately, the poor preservation of the front and the anterolateral margins does not permit further definition.

The fossil record for Cancer $\boldsymbol{s} . \boldsymbol{l}$. was reported to extend into the Miocene by Glaessner (1969) and Nations (1975). The oldest verifiable occurrence of Cancer s. s., based upon dorsal carapace morphology, is Cancer fujinaensis from Miocene rocks of Japan (Sakumoto, Karasawa, and Takayasu, 1992), and Karasawa (1990) described Cancer tomowoi from early to early middle Miocene rocks of Japan based on fingers and a portion of the sternum. North American fossil occurrences include C. fissus, from the Pliocene of California and $C$. productus from Pliocene and Pleistocene rocks of Alaska to California. Reports of C. productus are based only upon claw fragments. The genus appears to have evolved in the North Pacific Ocean, perhaps during the Miocene, and subsequently dispersed throughout the North Pacific and Atlantic Oceans by the Pliocene or Pleistocene. Recent species of Cancer inhabit the Northeast and Southeast Pacific Ocean and the North Atlantic Ocean, suggesting dispersal across the equator to the southern hemisphere and to the Atlantic Ocean through the Straits of Panama.
Anatolikos new genus

Cancer (Glebocarcinus) Nations, 1975, p. 23, 44, fig. 30.9; Karasawa, 1990, p. 7, pl. 1, fig. 10; Karasawa, 1993, p. 50, pl. 10, fig. 3; Karasawa, 1997, pl. 11, fig. 7.

Cancer (Cancer) Nations, 1975, p. 23, 44, fig. 6, 41.3, 41.4.

Type Species. - Cancer japonicus Ortmann, 1893 by original designation.

Diagnosis. - Carapace wider than long; front produced beyond orbits, with five coalesced spines including inner-orbital spines, separated by fissures; anterolateral margin with 10-12 spines, spines separated by fissures, third and fourth, fifth and sixth, seventh and eighth, and ninth and tenth spines paired.

Description. - Carapace wider than long, maximum length 70 to 80 percent maximum carapace width, carapace widest at position of penultimate or last anterolateral spine, located about threequarters the distance posteriorly on the carapace; carapace regions moderately well-defined, especially axial, protogastric, and metabranchial regions; carapace surface granular. Front projected beyond orbits, nearly straight, with five spines including inner-orbital spines, frontal spines lobate, separated by fissures. Fronto-orbital width from 31 to 46 percent maximum carapace width; orbits with thickened rim and two fissures. Anterolateral margin convex, most convex posteriorly; with $10-12$ spines, separated by fissures, triangular at tips; outer-orbital spine small, not well developed; second spine singular, sharp; third and fourth, fifth and sixth, seventh and eighth, and ninth and tenth spines paired; eleventh and twelfth spines, if present, singular and sharp. Posterolateral margin nearly straight or concave, rimmed, entire or with one spine. Posterior margin nearly straight, rimmed. Regions moderately well defined, especially axial, protogastric, and metabranchial regions; surface of carapace granular.

Manus of cheliped short; outer surface with three granular ridges and scattered tubercles; upper margin with three short spines; lower margin keeled. Fixed finger short, medially keeled; large, blunt denticles on occlusal surface. Movable finger short, 
granular, with small, blunt denticles on occlusal surface.

Etymology. - The generic name is taken from the Greek, "anatolikos," eastern, recognizing that the genus appears to be endemic to Japan.

Occurrence. - The new genus is currently known only from Japan. The two Recent species, $A$. japonicus and $A$. tumifrons have been reported from waters surrounding Japan (Nations, 1975), and $A$. itoigawai is known from the early to early middle Miocene of southwestern Japan (Karasawa, 1990; 1993).

Remarks. - Both Anatolikos japonicus and A. tumifrons were originally referred to the genus Cancer. Subsequently, Nations (1975) placed $C$. japonicus in the subgenus Cancer (Cancer) and C. tumifrons within Cancer (Glebocarcinus). Karasawa (1990) placed C. itoigawai within Cancer (Glebocarcinus). It is clear that these three species form a related group within the Cancrinae in possessing a nearly straight, produced front composed of five coalesced spines separated by fissures. No other cancrid genus exhibits frontal spines of this nature. Additionally, the shape and arrangement of anterolateral spines in the new genus are unique within the subfamily. The anterolateral spines are separated by fissures which may be closed or slightly open, and the orbits exhibit a thickened, broad rim, differentiating Anatolikos from all other genera of the subfamily. Anisospinos new genus, to be described below, also has a thickened orbital rim; however, the long, sharp, separated, and forward curving spines of Anisospinos immediately distinguish members of that genus from Anatolikos.

Anatolikos appears to have evolved in Japan during the early Miocene and has subsequently remained endemic to that region. The modern species $A$.tumifrons is especially similar to the fossil species $A$. itoigawai; $A$. japonicus differs from these two species in possessing twelve anterolateral spines instead of ten and an overall wider carapace. Evolution within the group has apparently remained relatively conservative, resulting in a small, narrowly defined genus.

\section{Anisospinos new genus}

Cancer Imaízumì, 1962, p. 239, pl. 40, fig. 15.

Cancer (Romaleon) Berglund and Goedert, 1992, p. 4; Karasawa, 1990, p. 6.

Type species. - Cancer (Romaleon) wahkiakumensis Berglund and Goedert, 1992, by original designation.

Diagnosis. - Carapace with five evenly-spaced frontal spines including inner-orbital spines; orbits broad, deeply excavated, with well-developed rim; anterolateral margin with eight spines including outer-orbital spine, spines separated to bases; third and fourth, fifth and sixth, and seventh and eighth anterolateral spines paired. Posterolateral margin entire, rim weak if present; carapace regions distinct, granular or ornamented with tubercles. Manus with two to four keels on outer surface and sharp spines on upper margin of manus and movable finger.

Description. - Carapace hexagonal, wider than long; moderately vaulted longitudinally and transversely. Front slightly projected beyond orbits, with five spines including inner orbital spines, spines evenly späced, medial spine sharp, lateral spines extending as ridge onto protogastric region, front about 30 percent maximum carapace width. Orbits directed weakly anterolaterally, broad, deeply excavated; with wide, well-developed rim; two orbital fissures; fronto-orbital width ranging from 40-55 percent maximum carapace width. Anterolateral margin with eight spines including outer-orbital -spine; spines separated to bases, granular, often curving anteriorly; outer-orbital spine sharp; second spine long, sharp; third and fourth, fifth and sixth spines, seventh and eighth spines paired; each anterolateral spine of different size and shape from any other. Posterolateral margins entire, very weak rim if present. Posterior margin convex. Carapace regions distinct; granular or ornamented with tubercles.

Chelae equal; manus long, ornamented with two to four keels on outer surface; keel on lower margin of manus serrate; keel on upper margin with several sharp or blunt spines. Fixed finger with grooves parallel to upper and lower margins, oc- 
clusal surface with denticles of varying sizes. Upper margin of movable finger with three distally directed spines; occlusal surface with several blunt denticles of varying size.

Etymology - The generic name is derived from the Greek "anisos," unequal, and "spinos," spine, describing the unequal nature of the anterolateral spines, a diagnostic feature of the genus.

Occurrence. - Anisospinos is known from the late Eocene Hoko River Formation, western Olympic Peninsula, Washington, USA, and the Miocene Astoria Formation, southwestern Washington, USA (Berglund and Goedert, 1992). One species is known from the middle Miocene Odose Formation in Japan (Karasawa, 1990).

Remarks. - Cancer wahkiakumensis was originally referred to Cancer (Romaleon) by Berglund and Goedert (1992) who noted that $C_{\text {. }}\left(R_{\text {. }}\right)$ wahkiakumensis differed from all other species of the subgenus Romaleon in the shape of the carapace, arrangement of carapace regions and in anteriorly directed anterolateral spines of differing sizes and shapes. Additionally, they noted that C. (R.) wahkiakumensis possessed only eight anterolateral spines while other species of Cancer (Romaleon) have nine spines. Finally, those authors observed that C. (R.) wahkiakumenis lacks posterolateral spines or rims, which all other species of Romaleon possess. The discovery of a new species from the Hoko River Formation prompts description of a new genus, Anisospinos, which includes $C$. wahkiqkumensis, $C$. odosensis, and a new species to be described below.

Anisospinos is distinguishable from all other genera of the Cancridae based upon its possession of eight anterolateral spines that are separated to their bases, the last six of which occur in pairs. No other cancrid genus exhibits such anterolateral ornamentation. Additionally, the orbits of Anisospinos are deeply excavated, broad, and broadly rimmed, a suite of orbital characters not exhibited by any other cancrid genus. Finally, Anisospinos differs from all of the genera in lacking posterolateral spines or rims.

Anisospinos is most similar to the genus Ro- maleon, but differs from it in several aspects. In Romaleon, the middle three frontal spines are closely spaced, while in Anisospinos, they are more evenly spaced. The lateral frontal spines of Anisospinos extend onto the protogastric region in a long, well-developed ridge; that ridge is shorter and much less well-developed in members of Romaleon. Members of Anisospinos possess deeply excavated, wide orbits that have a broad, well-developed rim. Species of Romaleon have shallower, narrower orbits that lack a rim. All species of Romaleon have nine unpaired anterolateral spines; in Anisospinos, there are eight anterolateral spines, the last six of which occur in pairs. The posterolateral margin of species of Romaleon is ornamented either with a beaded rim or a rim plus one posterolateral spine; Anisospinos has no spines and a very weak rim if present at all. The carapace regions of members of Romaleon are smooth or finely granular, while those of Anisospinos are granular or ornamented with large tubercles. Finally, the manus of the chelipeds in Romaleon is ornamented with well-developed keels composed of spines or large granules, whereas in Anisospinos, those keels are much more poorly developed. Because of these numerous differences, Anisospinos is easily distinguished from Romaleon.

Anisospinos is known from late Eocene and Miocene rocks of Washington. Anisospinos odosensis occurs in middle Miocene rocks of Japan. This suggests that the genus evolved in the northeastern Pacific Ocean during the Eocene and subsequently dispersed to Japan via surface ocean currents or along the Aleutian Island Arc. Additional fossil occurrences of Anisospinos along the North Pacific rim will be necessary to confirm this dispersal pattern.

The Japanese species Anisospinos odosensis was originally referred to Cancer by Imaízumi (1962) and was later referred to Cancer (Romaleon) by Karasawa $(1990,1993,1997)$. This species is referrable to Anisospinos based upon its possession of paired, sharp anterolateral spines that are separated to their bases. Additionally, each anterolateral spine is different in size from any other spine. The orbits of $C$. odosensis are broad, deeply excavated, bifissured, and rimmed. Cancer odosensis possesses an entire posterolateral margin that is unrimmed and a produced front. All of these characters are 
diagnostic of the new genus; therefore, $C$. odosensis is referred to Anisospinos. Karasawa (1993, 1997) illustrated a specimen (MFM83202) that he referred to Cancer sanbonsugii. Examination of that specimen and comparison to the holotype of Cancer odosensis indicates that MFM83202 is a member of $C$. odosensis, based upon possession of paired, sharp and well-developed anterolateral spines, overall carapace shape, regional shape and development, and orbital size and shape.

\section{Anisospinos berglundi new species}

(Figs. 2-3)

Diagnosis. - Carapace broadly hexagonal, wider than long, widest at position of last anterolateral spine; frontal margin with five evenly spaced spines including inner-orbital spines; orbits deeply excavated, wide, with broad rim; anterolateral margin with eight spines including outer-orbital spine; third and fourth, fifth and sixth, and seventh and eighth anterolateral spines paired; posterolateral margin entire; chelae equal; mani of chelae with keels on upper and lower margins and outer surface.

Description. - Carapace hexagonal, wider than long, $\mathrm{L} / \mathrm{W}=0.74$; carapace widest at position of last anterolateral spine, located about two-thirds distance posteriorly on carapace; carapace regions moderately to weakly inflated, defined by shallow grooves; carapace surface with sparse granules and scattered larger tubercles; carapace moderately vaulted transversely and longitudinally.

Front with five spines including inner orbital spines; axial spine small, blunt-tipped; spines on either side of axial spine broadest of frontal spines, separated from axial spine by shallow, u-shaped notch; inner orbital spines narrow, sharp, directed forward, separated from frontal spines by deeper, $\mathrm{v}$-shaped notch; front about 27 percent maximum carapace width.

Fronto-orbital width about 55 percent maximum carapace width; orbits broad, circular, directed forward, with wide rim; two orbital fissures, inner orbital fissure at about midwidth of orbit, outer orbital fissure located just proximal to outer orbital spine.
Anterolateral margin weakly convex, with eight spines including outer orbital spine; posterior margins of spines sometimes granular. First spine (outer orbital spine) sharp, narrow, directed forward. Second anterolateral spine broadly triangular, directed forward, anterior margin concave, posterior margin weakly convex. Third and fourth anterolateral spines paired; third spine narrow, attenuated, separated from second spine by deep, narrow reentrant, directed forward, anterior margin weakly concave, posterior margin weakly convex; fourth anterolateral spine broadly triangular, directed weakly anterolaterally, separated from third spine by shallow notch. Fifth and sixth anterolateral spines paired; fifth spine small, triangular, sharp, directed weakly anterolaterally, separated from fourth spine by v-shaped notch; sixth spine broadly triangular, sharp, directed strongly anterolaterally, upper margin nearly straight, lower margin convex, separated from fifth spine by broad, shallow notch. Seventh and eighth spines paired; seventh spine narrow, short, sharp, anterior margin weakly concave, posterior margin weakly convex, directed strongly anterolaterally; eighth spine longest, attenuated, directed laterally, separated from seventh spine by u-shaped notch. Short, shallow groove extending onto hepatic region from between second and third anterolateral spines; longer shallow groove extending onto hepatic region from between fourth and fifth anterolateral spines; longer, shallow groove extending onto carapace from between sixth and seventh anterolateral spines.

Posterolateral margins sinuous, concave anteriorly and convex posteriorly, entíre; posterior margin weakly convex, about 32 percent maximum carapace width.

Protogastric region triangular in shape, moderately inflated, ornamented with scattered tubercles, with longitudinal ridge parallel and adjacent to mesogastric process, extending from two frontal spines on either side of axial spine about one-third distance posteriorly on protogastric region; inner margin of protogastric region weakly convex, outer margin weakly convex. Mesogastric region narrow anteriorly, broadened posteriorly, lateral margins concave, distal margin weakly convex. Urogastric region inflated, anterior margin concave, lateral margins concave, posterior margin weakly convex. 


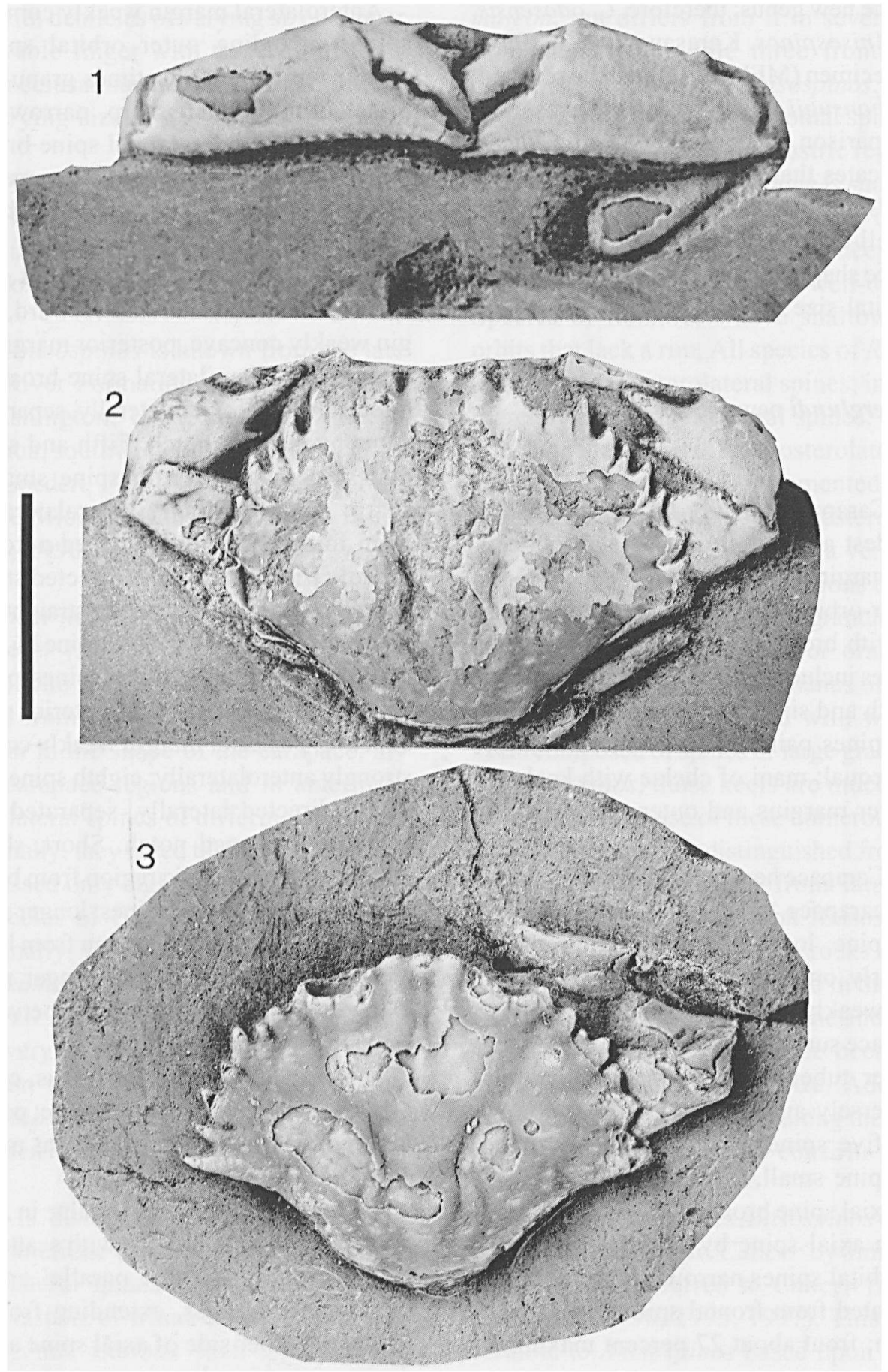

Fig. 2. Anisospinos berglundi n. gen. and sp. 1, Anterior view of holotype, USNM 507767. 2, Dorsal carapace of holotype, USNM 507767. 3, Dorsal carapace of paratype, USNM 507768. 


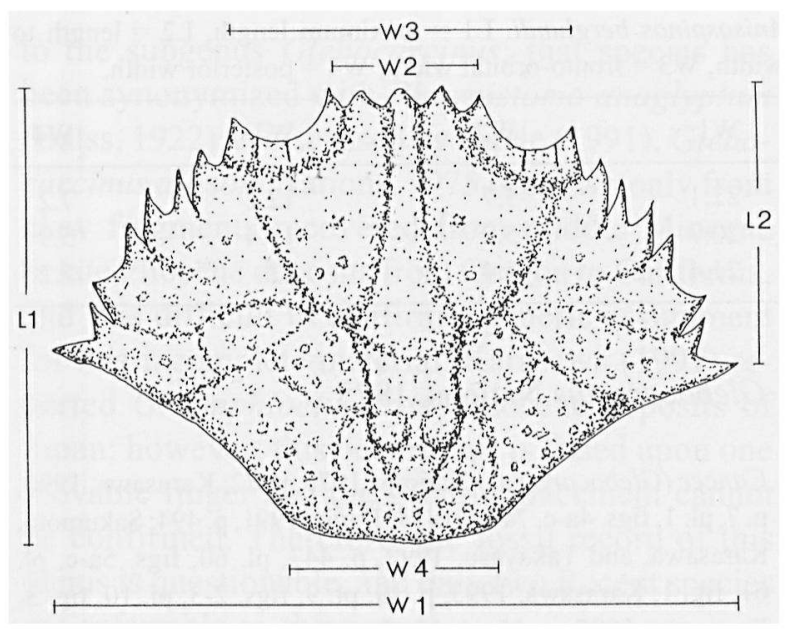

Fig. 3. Line drawing of Anisospinos berglundi showing the position and orientation of measurements taken.

Cardiac region rounded-triangle in shape, apex directed posteriorly, two large swellings anteriorly, one rounded swelling posteriorly. Intestinal region flattened, not well differentiated.

Hepatic region weakly inflated, ornamented with scattered tubercles. Epigastric region inflated centrally and flattened laterally, ornamented with scattered tubercles. Mesobranchial region inflated, ornamented with scattered tubercles. Metabranchial region flattened, ornamented with several large tubercles, with semi-lunar swellings adjacent to and on either side of cardiac region.

Chelipeds equal. Manus of cheliped longer than high, length to height ratio about 0.44 , becoming higher distally; proximal margin convex, with small, blunt, spine at upper corner and long, blunt spine at lower corner; lower margin developed into sinuous, serrate, keel, convex near proximal margin and concave near distal margin; upper margin with sharp keel ornamented with about five blunt nodes; distal margin sinuous, oriented at about 120 degree angle to upper margin, with broad, blunt swelling at midheight; outer surface of manus ornamented with tubercles on upper half, with weakly developed central keel, best developed distally; very weakly developed keel between upper margin and central keel, best developed centrally.

Fixed finger highest proximally and narrowed distally, height to length ratio about 0.56 ; with weakly hooked tipped; upper margin with variably sized, blunt denticles; outer surface with shallow grooves parallel to upper and lower margins.

Movable finger highest proximally and narrowed distally, height to length ratio about 0.39 ; upper margin convex, with three spines, first spine shortest and blunt, second and third spines long, narrow and sharp, all three spines directed distally; occlusal surface concave, with several variably sized blunt denticles.

Carpus of cheliped slightly longer than high, globular; outer surface convex, ornamented with a few tubercles; upper margin with sharp spine at distal corner and smaller, sharp spine just proximal to long spine, remainder of upper margin nearly straight; distal margin convex, with blunt projection at mid-height; lower margin convex; proximal margin nearly straight, with sharp triangular spine at upper corner; merus not well known.

Remainder of venter and appendages not known.

Meäsurements. - Measurements (in mm) taken on specimens of Anisospinos berglundi are given in Tables 1 and 2. Position and orientation of measurements taken are illustrated in Fig. 3.

Etymology. - The trivial name honors Ross E. Berglund, Bainbridge Island, WA, who has made a significant contribution to the study of the Cancridae of the Pacific Northwest of North America.

Types. - The holotype, USNM 507767, and three paratypes, USNM 507768-507770, are deposited in the United States Museum of Natural History, Smithsonian Institution, Washington, D. C.

Occurrence. - All of the specimens were collected from RB32, a locality in the late Eocene Hoko River Formation, located in the SW1/4, NW1/4, Sec. 4, T33N, R15W, Cape Flattery Quadrangle, 7.5' series, Clallam Co., Washington, several hundred meters inland from the south shore of the Strait of Juan de Fuca near a sanitary disposal site.

Remarks. - The new species differs from the closely related Anisospinos wahkiakumensis in several regards. Anisospinos berglundi has a broader frontoorbital width to maximum width ratio (55 percent) than does $A$. wahkiakumensis (40 percent). The ridges extending from the lateral frontal spines are 
Table 1. Measurements (in $\mathrm{mm}$ ) taken on the dorsal carapace of Anisospinos berglundi. $\mathrm{L} 1=$ maximum length, $\mathrm{L} 2=$ length to maximum width on carapace; $\mathrm{W} 1=$ maximum width, $\mathrm{W} 2=$ frontal width, $\mathrm{W} 3=$ fronto-orbital width, $\mathrm{W} 4=$ posterior width.

\begin{tabular}{lllllll}
\hline Specimen Number (USNM) & L1 & L2 & W1 & W2 & W3 & W4 \\
\hline 507767 & 16.2 & 10.6 & 22.1 & 5.7 & 12.2 & 7.2 \\
507768 & 14.7 & 10.3 & 20.7 & 5.2 & 11.4 & 5.9 \\
507769 & 17 & 10.8 & 21.4 & 6.4 & 12 & 7.2 \\
\hline
\end{tabular}

Table 2. Measurements (in mm) taken on the manus of the chelipeds of the holotype of Anisospinos berglundi, USNM 507767. $\mathrm{H} 1=$ maximum height of manus, $\mathrm{L} 1=$ maximum length of manus including fixed finger, L2 = length of fixed finger, L3 $=$ length of movable finger, $\mathrm{H} 2=$ height of fixed finger, $\mathrm{H} 3=$ height of movable finger.

\begin{tabular}{lllllll}
\hline & H1 & L1 & L2 & L3 & H2 & H3 \\
\hline Left & 6.5 & 14.7 & 4.7 & N/A & 2.7 & 3.0 \\
Right & 6.4 & 15.0 & 5.4 & 7.7 & 2.8 & 3.0 \\
\hline
\end{tabular}

much better developed in A, wahkiakumensis. Anisospinos berglundi has more evenly spaced frontal spines of about the same size, while in $A$. wahkiakumensis, the middle three spines are more closely spaced. The anterolateral spines in $A$. berglundi are longer and better differentiated from each other than those of A. wahkiakumensis, and additionally, the shapes and sizes of the spines differ between the two species. In $A$. berglundi, the last anterolateral spine is long, attenuated, and directed weakly anterolaterally while in $A$, wahkiakumensis, that spine is short and directed weakly posteriorly. The seventh anterolateral spine of $A$. berglundi is narrow and short, while in $A$. wahkiakumensis, it is broad and triangular in shape. Anisospinos wahkiakumensis has dense granules, while $A$. berglupdi is ornamented with sparse granules and scattered larger tubercles on the gastric and branchial regions. The two species differ in several aspects of the first perieopods. Anisospinos wahkiakumensis is rather ornamented on the chelae; the manus has a larger keel and much larger serrations on the lower margin of the manus; the outer surface of the manus has better developed keels and a much larger spine at the upper distal corner of the manus. Anisospinos berglund $i$ differs from $A$. odosensis in possessing broader, longer anterolateral spines, a broader orbital rim, and a much more granular carapace.

\section{Glebocarcinus Nations, 1975}

Cancer (Glebocarcinus) Nations, 1975, p. 22; Karasawa, 1990 , p. 7, pl. 1, figs. 4a-c, 7a-b, 10-14; Davie, 1991, p. 494; Sakumoto, Karasawa, and Takayasu, 1992, p. 447, pl. 60, figs. 5a-c, pl. 61, fig. 1; Karasawa, 1993, p. 49, pl. 9, figs. 2-3, pl. 10, fig. 3; Karasawa, 1997, p. 45, pl. 11, figs. 2, 7.

Type Species. - Cancer oregonensis Rathbun, 1898 by original designation.

Diagnosis. - Carapace length about three-quarters maximum width. Front not produced beyond orbits; with five spines including inner-orbital spines, inner three spines closely spaced, medial spine at lower level than other frontal spines; frontal region axially sulcate, sulcus extending from position of medial frontal spine. Fronto-orbital width about 46 percent maximum carapace width; orbits moderate sized, directed weakly anterolaterally, with two fissures. Anterolateral margin with nine spines, separated to bases, directed forward, sharp, with granules or spinelets; spines two and three and four and five may be paired. Posterolateral margin nearly straight or weakly concave, rimmed, with two small spines. Posterior margin rimmed, straight. Regions inflated, densely granular, defined by broad grooves.

Manus of chelipeds short; five rows of tubercles on outer surface; lower margin smooth; upper margin with four granular, blunt projections. Fixed finger short; narrow at tip, with two rows of tubercles; occlusal surface with large, blunt denticles. Movable finger with hooked tip, markedly narrowed distally; two rows of granules, one on upper margin and one on outer surface; occlusal surface with very short, blunt denticles.

Remarks. - Nations (1975) referred five species to the subgenus Glebocarcinus. Of these, Cancer (Glebocarcinus) tumifrons has been removed to Anatolikos. Nations (1975) referred Cancer balssi 
to the subgenus Glebocarcinus; that species has been synonymized with Platepistoma anaglyptum (Balss, 1922) as discussed by Davie (1991). Glebocarcinus allisoni Nations, 1975 is known only from claw fragments recovered from middle Miocene to late Pliocene deposits from Oregon to California, and it is difficult to confirm a generic assignment for this incomplete material. Karasawa (1997) reported G. amphioetus from Pliocene deposits of Japan; however, this occurrence is based upon one movable finger and the generic placement cannot be confirmed. Therefore, the fossil record of this genus is questionable, and only two Recent species are referrable to the genus.

The two species of the genus form a small, tightly defined group restricted to the North Pacific rim. Glebocarcinus oregonensis occurs from Alaska to California, and $G$. amphioetus has been reported from China, Korea, Japan, California, and Baja California. The genus probably evolved in the North Pacific Ocean and subsequently dispersed throughout that region, never becoming a speciose group.

\section{Metacarcinus A. Milne Edwards, 1862}

Cancer (Metacarcinus) Nations, 1975, p. 23; Williams, 1984, p. 351; Sakumoto, Karasawa and Takayasu, 1992, p. 447, pl. 60, figs. 5a-c, pl. 61, fig. 1; Karasawa, 1993, p. 50,pl. 10, fig. 4; Berglund and Goedert, 1996, p. 830, figs. 2, 3 Karasawa, 1997, p. 46, pl. 10, figs. 2-3.

Type Species. - Cancer magister Dana, 1852 by original designation.

Diagnosis. - Carapace ovate, about two-thirds wider than long. Front with five spines including innerorbital spine, inner three spines closely spaced; front usually not produced beyond orbits. Fronto-orbital width about 0.26-0.34 maximum carapace width; orbits shallow, directed forward. Anterolateral margin with nine or ten spines; anterolateral spines variable in form; small, sharp, and separated to bases or small, sharp and fissured; spine margins simple, serrate, or granular. Posterolateral margins rimmed, sometimes with one spine; carapace regions poorly developed, smooth or ornamented wtth fine granules.

Manus of chelipeds long; usually with four keels on outer surface, keels granular or smooth; lower margin with smooth or granular keel; upper margin with numerous sharp spines, granular, or with smooth keel; distal margin extending at approxímately 120 degree angle to upper margin. Fixed finger with central keel and another on lower margin; occlusal surface with sharp denticles. Movable finger with sharp spines, granules, or smooth keel on upper surface; occlusal surface with large, sharp dentícles.

Remarks. - Species of the genus Metacarcinus share possession of a relatively smooth dorsal carapace; nine or ten fissured or small, serrate or granular anterolateral spines, and rimmed posterolateral margins which may be ornamented with one spine. Of the taxa assigned to the genus by Nations (1975), M. plebejus has been removed as discussed for Cancer s. s. Metacarcinus granti was referred to Romaleon by Nations (1975); however, it is herein placed within Metacarcinus because it possesses fissured anterolateral spines with sharp, serrate terminations, a diagnostic feature for the genus.

The chelae of species assigned to this genus are of two major types. In Metacarcinus anthonyi, $M$. danai, $M$. davidi, $M$. edwardsii, $M$. gracilis, $M$. jenniferae, $M \times$ novaezealandiae, and $M$. granti, the claws resemble those of Cancer $s$. s. spp. because they possess short mani and fingers typical of Cancer s. s. and spined or smooth keels. The claws of $M$. magister resemble those of Romaleon because they have long mani and fingers ornamented with prominent spines. Therefore, the morphology of the chelae is not diagnostic for this genus. However, all of the species are readily assignable to this genus based upon dorsal carapace morphology, particularly the shape of the anterolateral spines.

The oldest verifiable occurrence of Metacarcinus based upon dorsal carapace morphology is $M$. goederti new species from Oligocene rocks of Alaska (but see discussion of Metacarcinus sp. below). Metacarcinus starri was described from early Miocene rocks of the Pysht and Clallam formations of Washington, USA. Metacarcinus danai has been reported from the Miocene of California, and $M$. jenniferae was reported from the middle Pliocene of California. Metacarcinus davidi is represented by carapace material and claw material from middle 
Miocene to middle Pliocene rocks of California. The two Japanese species of the genus are known from dorsal carapace material and include the Miocene $M$. izumoensis and the Pliocene $M$. minutoserratus. Metacarcinus magister, M. gracilis, and $M$. anthonyi are known almost exclusively from claw fragments from Pliocene and Pleistocene rocks of the west coast of North America. Because the oldest occurrence of the genus is in North America, it is suggested that the genus evolved in the North Pacific, as early as the Oligocene, and subsequently dispersed throughout the North Pacific Ocean by the Miocene. The genus has a similar distribution as that of Cancer s. $s$. in modern oceans, inhabiting the northeastern, southeastern, and southwestern Pacific and the North Atlantic Oceans. The similar geographic and chronologic distributions of Metacarcinus and Cancer $s$. $s$. suggest that they are especially closely related.

\section{Metacarcinus goederti new species}

(Figs. 4-5)

Diagnosis. - Carapace wider than long, widest at position of last anterolateral spine located about 60 percent distance posteriorly on carapace; carapace surface smooth or finely granular, regions weakly defined; orbits large for genus; anterolateral margin with nine sharp spines separated to bases, ornamented with fine granules; posterior margin entire, rimmed.

Description. - Carapace wider than long, fength about 68 percent maximum width, widest at position of last anterolateral spine located about 60 percent distance posteriorly on carapace; carapace regions weakly inflated, delimited by shallow grooves; surface appearing to be relatively smooth or finely granular; carapace vaulted both longitudinally and transversely.

Front about 16 percent maximum carapace width, not projected beyond orbits. Front with five spines including inner-orbitál spines, medial spine longest, narrow, lateral spines short, blunt, narrow; innerorbital spines separated from lateral spines by broad, u-shaped emargination, shortest of frontal spines, broadly triangular.
Fronto-orbital width about 32 percent maximum carapace width; orbits circular, directed forward; two orbital fissures, inner fissure at about mid-width of orbit, outer fissure just proximal to outer orbital spine.

Anterolateral margin convex; with nine spines including outer-orbital spine, spines separated to bases, with concave anterior margins and convex posterior margins, separated from each other by sharp, v-shaped notches, spines appearing to be ornamented with granules. First spine the outerorbital spine, broad, directed forward, curving weakly toward axis; second spine curving axially, directed forward, smallest of anterolateral spines; third spine broad, directed forward, curving axially; fourth spine broad, directed forward; fifth spine about as broad as fourth, directed anterolaterally; sixth spine about as large as fifth, directed anterolaterally; seventh spine broadest of anterolateral spines, directed anterolaterally; eighth spine about as broad as fourth-sixth, directed anterolaterally; ninth spine small, triangular, sharp, directed laterally.

Posterolateral margin sinuous, with granular rim, initially nearly straight, then concave posteriorly. Posterior margin nearly straight, rimmed, 38 percent maximum carapace width.

Protogastric region triangular in shape, weakly developed, flattened near frontal region, inner and outer margins convex. Mesogastric region narrow anteriorly, broadened posteriorly; margins of anterior process concave; posterior margin weakly convex. Urogastric region not well-differentiated from other gastric regions, with concave lateral margins, anterior margin concave, posterior margin nearly straight. Cardiac region rounded triangular, apex directed distally, two rounded swellings anteriorly, smaller rounded swelling posteriorly. Intestinal region flattened, not well-developed.

Hepatic and branchial regions very weakly inflated, poorly developed. Metabranchial region with semi-lunar swellings adjacent to and on either side of cardiac region.

Pterygostomial region finely granular, with two subhepatic grooves. Suborbital margin appearing to have broad, triangular notch.

Remainder of venter and appendages not known.

Measurements, - Measurements (in mm) takęn on 


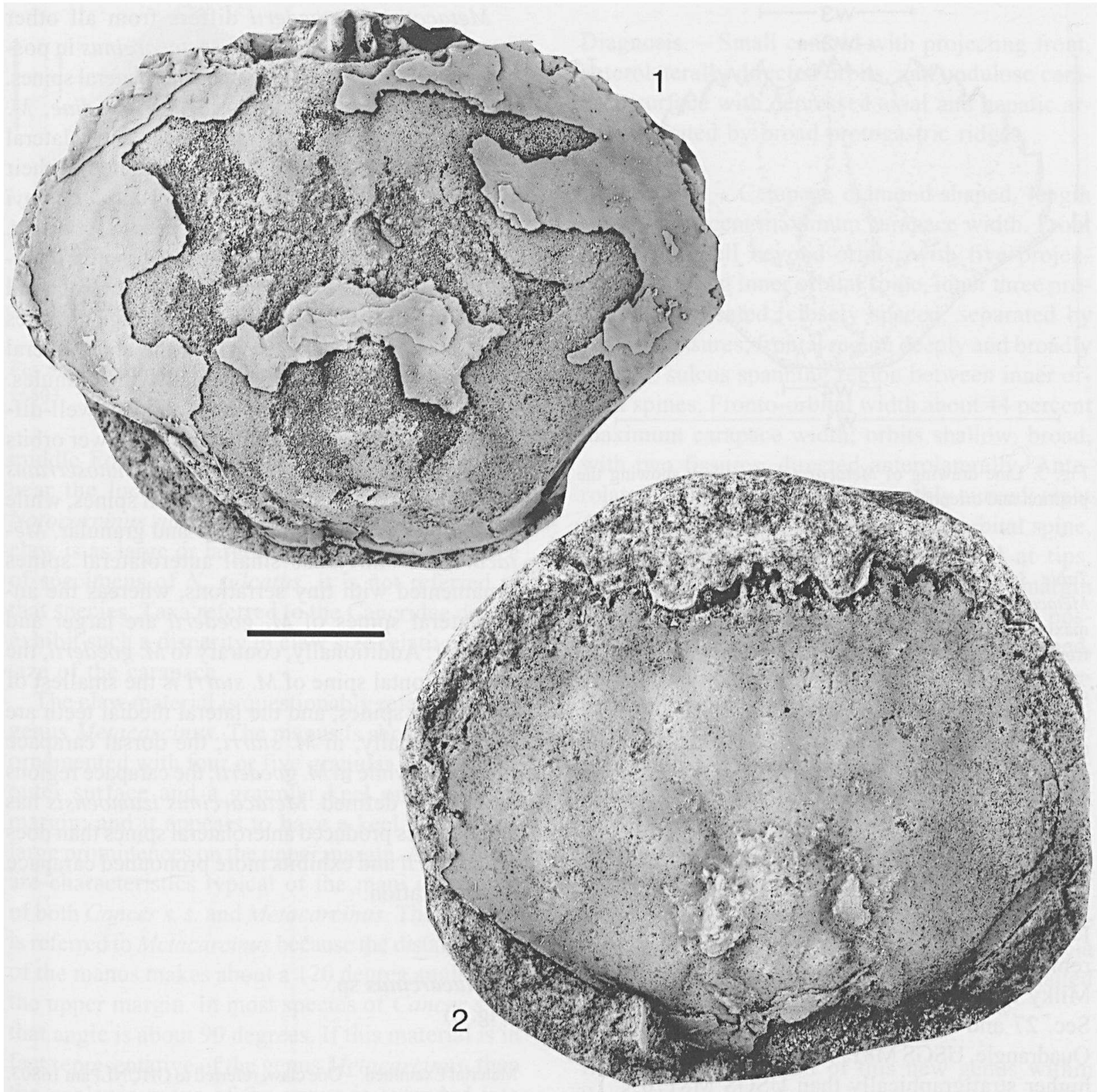

Fig. 4. Metacarcinus goederti n. sp. 1, Dorsal carapace of paratype, USNM 507772. 2, Dorsal carapace of holotype, USNM 507771.

specimens of Metacarcinus goederti are given in Table 3. Position and orientation of measurements taken are illustrated in Fig. 5.

Etymology. - The trivial name honors James L. Goedert, Gig Harbor, Washington, who has made a significant contribution to the study of the Cancridae of the Pacific Northwest of North America.
Types. - The holotype, USNM 507771, and four paratypes, USNM 507772-507774, are deposited in the United States National Museum of Natural History, Smithsonian Institution, Washington, D.C.

Occurrence. - The specimens were recovered from the Bear Lake Formation, questionably of Oligocene age, Alaska, USA. The holotype, USNM 507771, was collected from Sec. 27 or 34, T48S, R69W, 


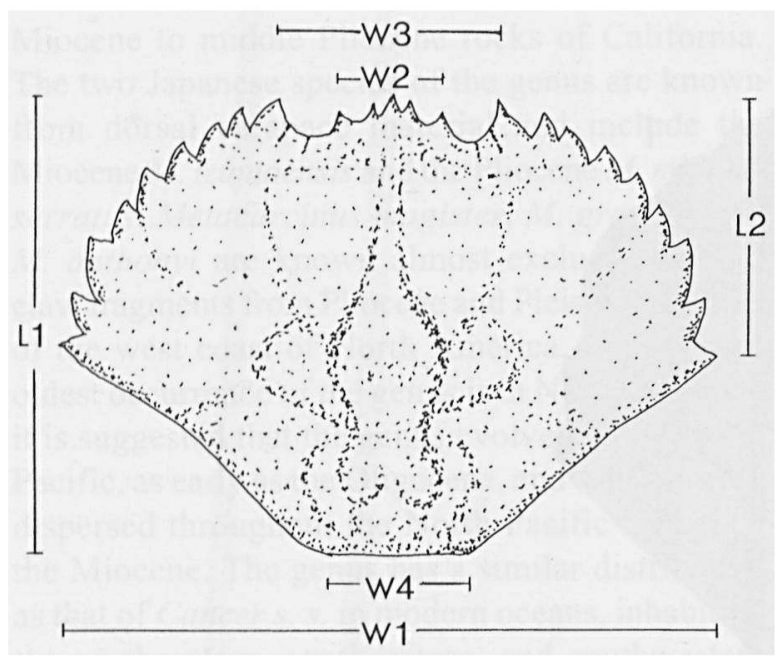

Fig. 5. Line drawing of Metacarcinus goederti showing the position and orientation of measurements taken.

Table 3. Measurements (in $\mathrm{mm}$ ) taken on specimens of Metacarcinus goederti. $\mathrm{L} 1=$ maximum length, $\mathrm{L} 2=$ length to maximum width on carapace; $\mathrm{Wl}=$ maximum width, $\mathrm{W} 2=$ frontal width, $\mathrm{W} 3$ = fronto-orbital width, $\mathrm{W} 4$ = posterior width.

Specimen

Number

\begin{tabular}{lllllll} 
(USNM) & L1 & L2 & W1 & W2 & W3 & W4 \\
\hline 507772 & 39.7 & 23.3 & 52.7 & 8.2 & 16.6 & 21.4 \\
507771 & 35 & 20.3 & 53.2 & 8.8 & 16 & N/A \\
507773 & 31.7 & 18.6 & 43.2 & 6.2 & 15.2 & 15.7 \\
\hline
\end{tabular}

Port Moller (D-1) Quadrangle, USGS M8170. The remainder of the material was collected from the Milky River section of the Bear Lake Formation, Sec. 27 and 34, T48S, R69W, Port Moller (D-1) Quadrangle, USGS M8171. USGS M8171 is slightly higher stratigraphically than USGS M8170.

Remarks. - The new species Metacarcinus goederti is placed within Metacarcinus based upon possession of nine anterolateral spines including the outerorbital spine; anterolateral spines that are distinctly separated and ornamented with granules; five frontal spines with the middle three closely spaced; a front not extending beyond the orbits; rimmed posterolateral and posterior margins; and indistinct carapace regions. Additionally, the new species lacks posterolateral spines, which is typical of many species of Metacarcinus.
Metacarcinus goederti differs from all other species referred to the genus Metacarcinus in possessing very well-differentiated anterolateral spines. Metacarcinus plebejus, $M$. novaezealandiae, $M$. davidi, and $M$. anthonyi all possess anterolateral spines that are fissured and not separated to their bases as in $M$. goederti. Metacarcinus anthonyi also has much smaller orbits than does $M$. goederti. Metacarcinus magister has a more granular carapace, shallower orbits, and smaller anterolateral spines ornamented with spinelets or large granules than does $M$. goederti, in which the anterolateral spines are simple or ornamented with granules. Metacarcinus danai has smaller and less well-differentiated spines and smaller and shallower orbits than does $M$. goederti. Metacarcinus minutoserratus has complex and serrate anterolateral spines, while those of $M$. goederti are simple and granular. Metacarcinus starri has small anterolateral spines ornamented with tiny serrations, whereas the anterolateral spines of $M$. goederti are larger and granular. Additionally, contrary to $M$. goederti, the medial frontal spine of $M$. starri is the smallest of the frontal spines, and the lateral medial teeth are largest. Finally, in $M$. starri, the dorsal carapace is smooth, while in $M$. goederti, the carapace regions are weakly defined. Metacarcinus izumoensis has smaller, less produced anterolateral spines than does $M$. goederti and exhibits more pronouned carapace ornamentation.

\section{?Metacarcinus sp.}

(Fig. 6)

Material Examined. - One claw, referred to GHUNLPam 16803, is deposited in the Paleontology collection of the Facultad de Ciencas Exactas y Naturales, Universidad Nacional de La Pampa, Santa Rosa, La Pampa, Argentina.

Occurrence. - The specimen was collected from the Centinela Formation, on the Estancia 25 de Mayo, about one $\mathrm{km}$ east of the locality described below for Notocarcinus sulcatus new species. The claw was collected just below the volcanic tuff described for $N$. sulcatus and is therefore middle Eocene in age.

Remarks. - One claw fragment was recovered from 


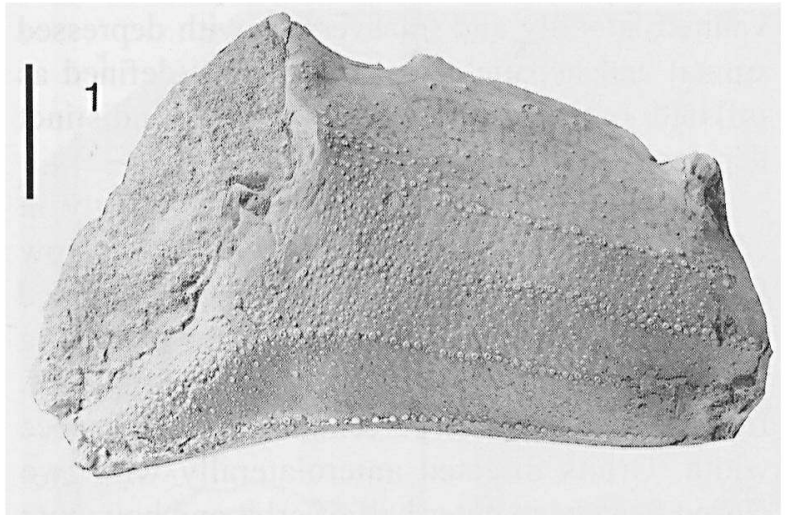

Fig. 6. ?Metacarcinus sp., outer view of cheliped, GHUNLPam 16803.

middle Eocene rocks of the Centinela Formation near the locality from which the specimens of Notocarcinus sulcatus were collected. Because the claw is as large or larger than the dorsal carapace of specimens of $N$. sulcatus, it is not referred to that species. Taxa referred to the Cancridae do not exhibit such a disparity in claw size relative to the size of the carapace.

The claw material is questionably referred to the genus Metacarcinus. The manus is short and high; ornamented with four or five granular keels on the outer surface and a granular keel on the lower margin; and it appears to have a keel with a few large prominences on the upper margin. All of these are characteristics typical of the mani of species of both Cancer s. s. and Metacarcinus. The material is referred to Metacarcinus because the distal margin of the manus makes about a 120 degree angle with the upper margin. In most species of Cancer s. s., that angle is about 90 degrees. If this material is in fact representative of the genus Metacarcinus, then the geologic range of the genus is extended into the middle Eocene. Furthermore, this might suggest a southern hemisphere origin for the genus with subsequent dispersal into the North Pacific Ocean by the Oligocene. Confident generic assignment awaits the discovery of dorsal carapace material.

\section{Notocarcinus new genus}

Type species. - Notocarcinus sulcatus new species by original designation.
Diagnosis. - Small cancrid with projecting front, anterolaterally directed orbits, and undulose carapace surface with depressed axial and hepatic areas separated by broad protogastric ridges.

Description. - Carapace diamond-shaped, length about 73 percent maximum carapace width. Front projecting well beyond orbits, with five projections including inner orbital spine, inner three projections truncated, closely spaced, separated by shallow fissures; frontal region deeply and broadly sulcate, sulcus spanning region between inner orbital spines. Fronto-orbital width about 44 percent maximum carapace width; orbits shallow, broad, with two fissures, directed anterolaterally. Anterolateral margin gently and smoothly curved; eight anterolateral spines, including outer orbital spine, spines separated by fissures, truncated at tips, margins of spines granular. Posterolateral margin very weakly concave, rimmed at least in the posterior half, not spined. Regions weakly developed, most prominently in the posterior axial area; hepatic, frontal, and epigastric areas depressed.

Etymology. - The name was derived from the Greek "notos," south, and "carcino," crab, in reference to the occurrence of the genus in the southern hemisphere.

Occurrence. - The genus is described from specimens collected at a single locality on the Estancia 25 de Mayo, near Calafate, Argentina. A detailed description of the locality is given below.

Remarks. - Placement of this new genus within the Cancrinae can be made with confidence. The carapace is wider than long, the frontal region bears five projections, the orbits exhibit two well-developed fissures, the anterolateral margin is divided into eight blunt projections separated from one another by distinct fissures, and the rimmed posterolateral margin lacks spines. However, several characteristics serve to distinguish the genus from others within the subfamily. The frontal margin projects well in advance of the orbits, and the three central projections of the front are blunt and separated by fissures whereas the outer projections, the 
inner orbital spines, are more distinctly separated and pointed. The orbits are directed anterolaterally and the frontal and epigastric regions, are deeply depressed and bordered by protogastric ridges extending from the orbits posteriorly and axially. Lateral to these ridges, the hepatic regions are depressed so that the entire front half of the carapace has an undulose surface. Whether this character is in fact diagnostic of the genus or is a species-level trait must await discovery of additional species within the genus. Regardless, the placement of the specimens within a unique genus seems certain.

The occurrence of Notocarcinus in middle Eocene rocks in Argentina is significant. Glaessner (1969) reported the range of the Cancridae to extend from middle Eocene to Recent; however, the Cancrinae were known only from Miocene to Recent occurrences at that time. The range of the Cancrinae has been extended into the middle Eocene as recorded by Notocarcinus, which is the oldest known occurrence of the subfamily. Perhaps even more significantly, the Cancrinae is currently widely distributed within the Pacific Ocean basin and in the North Atlantic. No cancrids are known from modern seas along the east coast of South America. In the fossil record, Beurlen (1958) reported ?Cyclocancer tuberculatus from the upper Oligocene or lower Miocene of Brazil and van Straelen (1937) described Parapirimela angolensis from West Africa. The Brazilian material was originally assigned to the Atelecyclidae. It may, in fact, be a cancrid; however, the assignment remains in doubt. The African occurrence is probably not a cancrid as discussed above. Thus, the occurrence of Notocarcinus sulcatus from Argentina is the first welldocumented cancrid, fossil or extant, known from the South Atlantic region.

\section{Notocarcinus sulcatus new species}

(Figs. 7-8)

Diagnosis. - As for genus.

Description. - Small cancrid; elongate ovoid outline, wider than long, length about 73 percent maximum width, carapace widest about 53 percent distance posteriorly on carapace; strongly vaulted laterally and transversely with depressed frontal and hepatic areas, other areas defined as inflated regions separated by broad, indistinct depressions.

Front generally straight, projected slightly in advance of orbital regions, with two short, narrow fissures defining three blunt teeth; front defined laterally by distinctly pointed corner extending posterolaterally to fissure at inner orbital tooth, frontal width about 19 percent maximum carapace width. Orbits directed anterolaterally with two closed fissures in outer half of orbit and bounding rounded projection, fronto-orbital width about 45 percent maximum carapace width. Anterolateral margin shorter than posterolateral margin, distinct, weakly upturned, gently convex in dorsal aspect, with eight blunt, undivided lobes, including outer orbital spine; lobes separated from one another by closed fissures. Posterolateral margin straight to slightly concave; posterior margin straight, wider than front, posterior width about 25 percent maximum carapace width. Prominent marginal rim borders posterior half of posterolateral margin and posterior margin.

Frontal region broadly sulcate, bounded by protogastric ridges converging posteriorly from inner orbital spine to elevated mesogastric region that is slightly longer than wide; metagastric region weakly distinguished from mesogastric by subtle transverse depression. Cardiac region circular, bearing two small nodes at about midlength. Intestinal area indistinct. Carapace surface granular, most distinctly on elevated regions and somewhat smoother in depressions.

Epistome weakly convex laterally, surface smooth.

Remainder of venter, abdomen, and legs not known.

Measurements. - All measurements were taken on the holotype, GHUNLPam16801. The paratype is incomplete. Maximum length, $22.9 \mathrm{~mm}$; length to maximum width on carapace, $12.2 \mathrm{~mm}$; maximum width, $31.4 \mathrm{~mm}$; frontal width, $6.1 \mathrm{~mm}$; frontoorbital width, $14.2 \mathrm{~mm}$; posterior width, $7.8 \mathrm{~mm}$.

Etymology. - The trivial name alludes to the depressed hepatic regions exhibited on the specimens 

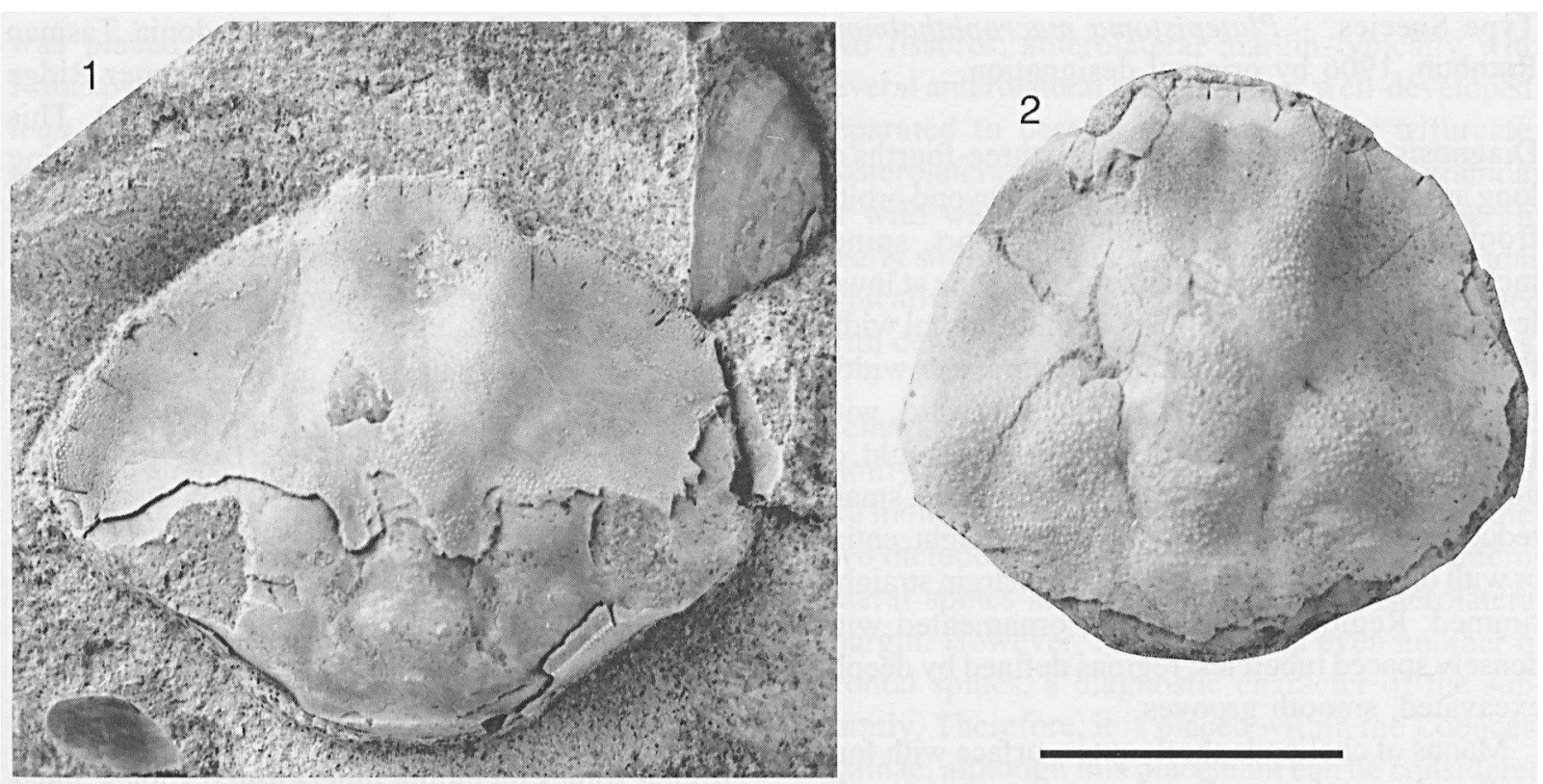

Fig. 7. Notocarcinus sulcatus n. gen. and sp. 1, Dorsal carapace of holotype, GHUNLPam 16801. 2, Dorsal carapace of paratype. GHUNLPam 16802.

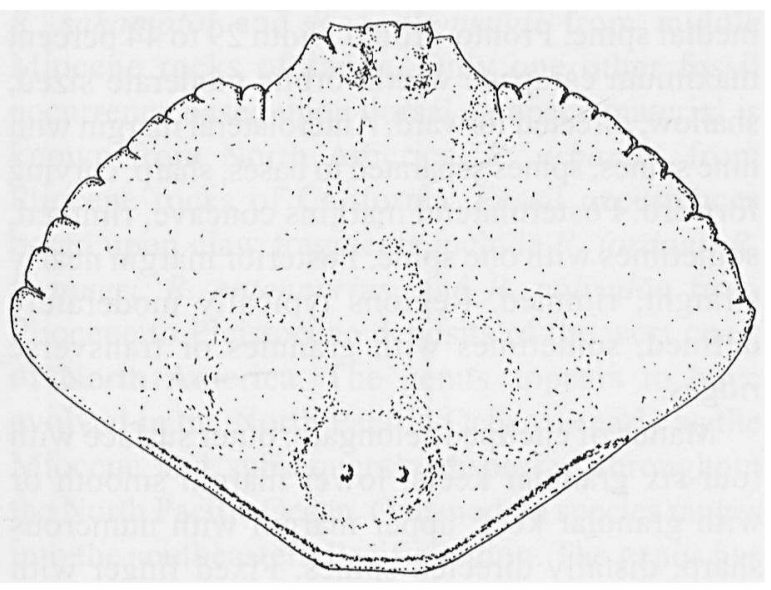

Fig. 8. Line drawing of Notocarcinus sulcatus.

that serve to distinguish this species from all other cancrids.

Types. - The holotype, GHUNLPam 16801, and paratype, GHUNLPam 16802, are deposited in the Paleontology collection of the Facultad de Ciencias Exactas y Naturales, Universidad Nacional de La Pampa, Santa Rosa, La Pampa, Argentina.

Occurrence. - The two specimens were collected from the Centinela Formation, middle Eocene, on the Estancia 25 de Mayo, Latitude $50^{\circ} 30.716^{\prime} \mathrm{S}$, Longitude $72^{\circ} 15.303^{\prime} \mathrm{W}$, ca. $12 \mathrm{~km}$ south from Calafate, Santa Cruz Province, Argentina. The deposits are dated at $46 \mathrm{ma}$ on the basis of a prominent volcanic tuff, exposed just above the site from which the crabs were collected (Casadio et al., 2000).

Remarks. - The two specimens are moderately well preserved in terms of the dorsal carapace; cuticle preserved on the anterior two-thirds of the carapace confirms that the ornamentation is limited to very fine granules. The species has a characteris-tic diamond-shaped outline, because the anterolateral margins are somewhat straighter than in most members of the family. However, the undulose nature of the anterior portion of the carapace and the relatively distinct definition of the posterior regions are certainly the most diagnostic features of this crab. It cannot be mistaken for any other cancrid.

\section{Platepistoma Rathbun, 1906}

Platepistoma Rathbun, 1906, p. 876.

Cancer (Platepistoma) Takeda, 1977, p. 35-38, fig. 4B. 
Type Species. - Platepistoma macrophthalmous Rathbun, 1906 by original designation.

Diagnosis. - Carapace hexagonal, three-fourths as long as wide. Front projected slightly beyond orbits; front with five poorly developed, short, spines including inner-orbital spines, medial spine at lower level than other frontal spines. Fronto-orbital width from 38 to 44 percent maximum carapace width; orbits shallow, very small, directed forward, with two fissures. Anterolateral margin with eight or nine spines; spines separated to bases, simple, small, reduced. Posterolateral margin nearly straight, entire or with one spine, rimmed. Posterior margin straight, rimmed. Regions well defined, ornamented with densely spaced tubercles; regions defined by deeply excavated, smooth grooves.

Manus of chelipeds short; outer surface with four or five rows of granules; lower margin smooth; upper margin with several short spines or granular. Fixed finger with two rows of granules, occlusal surface with large, blunt denticles. Movable finger smooth, occlusal surface with very short, blunt denticles or nearly smooth.

Remarks. - Davie (1991) provided a thorough discussion of this genus, a small, tightly defined group, and offered several means by which to differentiate members of Platepistoma from Cancer $s . l$, which have been expanded upon in the diagnosis. The Japanese species Cancer? imamurae has inflated carapace regions ornamented with densely spaced granules; deep grooves separating the carapace regions; short, poorly developed frontal spines; and small, poorly developed anterolateral spines. Cancer? imamurae differs from other members of Platepistoma in possessing several small spines on the posterolateral margin; however, this is the only significant difference between Cancer? imamurae and the other members of the genus. Therefore, it seems most prudent to place Cancer? imamurae within Platepistoma instead of erecting a monospecific genus for this species.

The two fossil species of this genus, Platepistoma imamurae and $P$. kaedei, are known from Miocene deposits of Japan. Modern members of the genus inhabit the Indo-Pacific region including occurrences in Hawaii, Japan, Madagascar, the Réunion
Islands, French Polynesia, New Caledonia, Tasman Sea, the Seychelles, and the Sala-y-Gomez Ridge of the southeastern Pacific (Davie, 1991). This suggests that the genus may have evolved during the Miocene in Japan and subsequently dispersed throughout the Indo-Pacific region.

\section{Romaleon Gistl, 1848}

Cancer (Romaleon) Nations, 1975, p. 23; Davie, 1991, p. 508; Berglund and Goedert, 1992, p. 4, figs. 2-16; Karasawa, 1993, p. 50, pl. 10, fig. 6; Karasawa, 1997, p. 45, pl. 10, fig. 6, 8 .

Type Species. - Cancer gibbosulus Rathbun, 1898.

Diagnosis. - Carapace 60 to 75 percent as long as wide. Front slightly produced beyond orbits; five frontal spines including inner-orbital spines, inner three spines very closely spaced, medial spine at lower level than other frontal spines; frontal region axially sulcate, sulcus extending from position of medial spine. Fronto-orbital width 29 to 44 percent maximum carapace width; orbits moderate sized, shallow, directed forward. Anterolateral margin with nine spines, spines separated to bases, sharp, curving forward. Posterolateral margins concave, rimmed, sometimes with one spine. Posterior margin nearly straight, rimmed. Regions typically moderately defined, sometimes with granules or transverse ridges.

Manus of chelipeds elongate; outer surface with four-six granular keels; lower margin smooth or with granular keel; upper margin with numerous sharp, distally directed spines. Fixed finger with two granular keels, occlusal surface with large, blunt denticles. Movable finger long; upper surface with distally directed spines or granules; occlusal surface with large, blunt denticles.

Remarks. - Members of the genus Romaleon are united by their possession of singular, anteriorlycurving anterolateral spines that are separated to their bases. Most members of the genus have elongate mani and fingers of the cheliped, and those elements are typically ornamented with spines or sharp granules.

Cancer nadaensis Sakai, 1969 was referred to Cancer (Cancer) by Nations (1975). That species 
was placed within the subgenus Romaleon by Karasawa (1990); it is herein placed within Romaleon. Kato (1996) figured three dorsal carapace specimens (figs. 5-5, 5-6b, 7) as members of the new species Cancer sakamotoi, here referred to the genus Romaleon. Examination of these figures indicates that the holotype specimen for $R$. sakamotoi, illustrated in fig. 7 (Kato, 1996), is indeed distinct. However, the carapace illustrated in figure 5-5 is referrable to Romaleon sanbonsugii based upon the shape of the anterolateral spines and the marked curvature of the anterolateral margin. The specimen figured in 5-5 differs from the holotype of C. sakamotoi in possessing small, broadly tríangular, spines, that are directed anterolaterally, while the holotype specimen has narrow, attenuated spines that are separate to their bases and curve weakly anteriorly.

The oldest known occurrences of Romaleon, based upon dorsal carapace morphology, are $R$. dereki from the middle Miocene of California and $R$. sakamotoi and $R$. sanbonsugii from middle Miocene rocks of Japan. Only one other fossil occurrence based upon dorsal carapace material is known from North America, R. urbanus, from Pliocene rocks of California. Fossil occurrences based upon claw fragments include $R$. jordani, $R$. branneri, $R$. antennarius, and $R$. polyodon from Pliocene to Pleistocene deposits of the west coast of North America. The genus appears to have evolved in the North Pacific Ocean as early as the Miocene and subsequently dispersed throughout the North Pacific Ocean. One modern species ranges into the southeastern Pacific region. The genus has a similar geographic distribution to that of Cancer and Metacarcinus, suggesting a close relationship between these three genera.

\section{Subfamily Lobocarcininae Beurlen, 1930}

Included genera. - Loböcarcinus Reúss, 1857; Miocyclus Müller, 1979; and Tasadia Müller in Janssen and Müller, 1984.

Diagnosis. - Carapace wider than long; front usually with even number of spines, ranging from four to six and if odd number of spines, central spine small and at lower level than other spines; orbits with two fissures; anterolateral margin typically with several anterolateral spines; spines well-developed, separated to base, often bifurcate or trifurcate; posterolateral margin typically coarsely granular or with well developed spines; posterior margin nearly straight, granular or spined; carapace regions typically moderately well-developed, ornamented with dense granules or with discrete, large spines.

Remarks. - The Lobocarcininae is a small subfamily comprised of three genera, two of which are monospecific. Miocyclus differs from the other two included genera in possessing fissured anterolateral spines and a smooth, entire posterolateral margin. However, it possesses an even number of frontal spines, a diagnostic character of the subfamily. Therefore, it is placed within the Lobocarcininae, although this placement can be considered to be provisional because the specimens have not been examined.

All of the genera within the Lobocarcininae have their earliest occurrence in or are known solely from the Tethys, and in fact, only one species of Lobocarcinus, L. pustulosus Feldmann and Fordyce, 1996, is extralimital. This suggests that the subfamily arose in the Tethyan region, as early as the middle Eocene, and subsequently dispersed into New Zealand waters.

\section{Lobocarcinus Reuss, 1857}

Type species. - Lobocarcinus paulinowuerttemburgensis von Meyer, 1847.

Diagnosis. - Carapace much wider than long. Front projected weakly beyond orbits; four to six frontal spines including inner orbital spines. Fronto-orbital width from 30 to 40 percent maximum carapace width; orbits round, with two fissures, directed forward; orbits rimmed. Anterolateral margin usually with seven lobes; lobes typically sharply bifurcate or trifurcate. Posterolateral margin nearly straight, with several spines of varying size. Posterior margin nearly straight, sometimes with spines. Regions moderately well-developed, often ornamented with several large nodes. Chelipeds slender and equal. 
Remarks. - Six species are referred to the genus Lobocarcinus. All are known from the Tethyan region with the exception of L. pustulosus, known from the Miocene of New Zealand (Feldmann and Fordyce, 1996). A complete discussion of the group was provided by Anderson and Feldmann (1995), who revised the genus and described a new species. Lobocarcinus pentanodosus Collins and Barber, 1998, was reported from Eocene rocks of Indonesia; however, that species has fewer anterolateral spines than do species of Lobocarcinus and the spines of $L$. pentanodosus are singular, not bifurcate or trifurcate as in authentic Lobocarcinus. The posterolateral margins of L. pentanodosus are entire, while those of authentic Lobocarcinus are spined. The carapace ornamentation of L. pentanodosus differs from that of authentic Lobocarcinus. Typical members of Lobocarcinus possess large granules on the carapace and rather well defined carapace regions. Lobocarcinus pentanodosus has poorly defined regions and transverse ridges on the protogastric regions. The transverse ridges and the possession of five, singular anterolateral spines suggest that $L$. pentanodosus may be a portunid.

Cancer sismondae is here referred to the genus Lobocarcinus based upon its possession of distinctly lobed anterolateral margins, spined posterolateral margins, and the overall shape of the carapace and carapace regions (Bonfiglio and Donadeo, 1982). The carapace regions appear to be ornamented with nodes, as is typical of many species of Lobocarcinus. The only difference between $L$. sismondai and other species of Lobocarcinus is that it possesses five frontal spines, including an axial spine instead of an even number as is typical of the genus/and subfamily. This constitutes a major difference; however, all other carapace characters clearly place L. sismondai within Lobocarcinus. The axial spine is smaller than the other spines and placed at a lower level, a condition seen in many members of the Cancrinae and which could represent convergence. It is also recognized that Cancer illyricus Bittner, 1893 and C. deshayesii A. Milne Edwards, 1861 are synonymous with $L$. sismondai (Glaessner, 1929; Müller, 1984; Collins and Fraaye, 1991). Specimens of these taxa were not seen by us, but the synonymy of these taxa is well-demonstrated in the cited works.
The genus is known only from the fossil record, occuring in middle to late Eocene rocks of Egypt, Hungary, and India; Miocene rocks of New Zealand; and Miocene to Pliocene rocks of the Mediterranean rim and Northern Europe. Feldmann and Fordyce (1996) suggested that the genus evolved in the Tethys and subsequently dispersed from that region into New Zealand. Members of this genus are the earliest known members of the subfamily.

Miocyclus Müller, 1979

Type species. - Miocyclus bulgaricus Müller, 1979.

Diagnosis. - Carapace wider than long, flattened, ornamented with small, dense granules; orbits with two fissures; front weakly projecting beyond orbits, with six frontal spines including inner-orbital spines; anterolateral margin crispate, with nine spines; first eight fissured, with blunt margins; last spine sharp, produced; posterolateral margin entire, nearly straight; posterior margin weakly convex.

Remarks. - Miocyclus is a monospecific genus known from the Miocene of Bulgaria. It was originally placed within the Atelecyclidae by Müller (1979) but was later moved to the Cancrinae based upon possession of wide mesogastric regions (Müller, 1984). The genus is here placed within the Lobocarcininae based upon possession of an even rather than odd number of frontal spines. The genus is easily distingushed from other members of the Lobocarcininae because it lacks well-developed bifurcate or trifurcate spines on the anterolateral margin and has a smooth, entire posterolateral margin.

Tasadia Müller in Janssen and Müller, 1984

Cancer Bittner, 1884, p. 27, pl. 1, figs. 8-9; Lörenthey, 1897, p. 159-160, 167-168.

Atelecyclus Lörenthey. Lörenthey in Lörenthey and Beurlen, 1929, p.156-158, pl. 9, fig. 9; gripp, 1969, pp. 86-87, pl. 3, fig. 1.

Cyclocancer (Lörenthey). Beurlen, 1958, p. 15.

Cancer (Glebocarcinus) Karasawa, 1990, p. 6. 
Type species. - Cancer carniolica Bittner, 1884.

Diagnosis. - Carapace wider than long, L/W about 0.60 . Front not projected beyond orbits, four or five frontal spines. Fronto-orbital width to width ratio about 30 percent; orbits small, shallow, directed forward, with two fissures. Anterolateral margin convex, ornamented with eight or nine triangular spines, with granules or spinelets, each separated to bases. Posterolateral margin nearly straight, granular, with several small spines. Posterior margin rimmed, nearly straight. Regions well defined, ornamented with densely spaced tubercles; regions defined by smooth, deep grooves.

Manus of chelipeds with at least four granular keels on outer surface; upper margin appearing to be ornamented with sharp spines; lower margin smooth. Fixed finger with two granular keels on outer surface. Movable finger with sharp granules on upper margin; at least one row of granules on outer surface.

Discussion - Davie (1991) suggested that this genus exhibited sufficient similarity to the genus Platepistoma that it may be synonymous with it, whereas Karasawa (1990) synonymized Tasadia with Cancer s. $l$. Examination of illustrations and casts of specimens of Tasadia (Müller in Janssen and Müller, 1984, pl. 5) indicates that it is indeed a distinct genus. Tasadia differs from members of Platepistoma in possessing distinct, large, triangular anterolateral spines, while the anterolateral spines of Platepistoma are small and reduced. Additionally, Tasadia possesses a multi-spined posterolateral margin, while that of Platepistoma typically only has one spine. The regions of Tasadia are not as densely ornamented, and the shape of the regions differs in Tasadia from those of Platepistoma. Tasasdia is also distinguishable from Glebocarcinus, members of which typically have narrow, anterolateral spines that are directed weakly anteriorly and sometimes ornamented with spinelets. The anterolateral spines of Tasadia are short, broad, and triangular and are ornamented with large granules. The carapace regions of Tasadia are not nearly as well developed and are more sparsely yet more coarsely ornamented than those of Glebocarcinius. The orbits are better developed in Glebocarcinus and the frontal spines are much better developed than in Tasadia. For all of these reasons, Tasadia is retained as a distinct genus. As far as is known, Tasadia is a monospecific genus restricted to the Miocene of Central Europe. Cancer bittneri Toula, 1904 was recognized to be synonymous with $T$. carniolica by Müller (1984).

\section{Discussion}

The biogeographic distribution of Cancer s. $l$, and by implication, the Cancridae, has been addressed on numerous occasions (Ekman, 1953; Nations, 1975; 1979; Carvacho, 1989; Newman, 1991). Ekman (1953), Nations (1975; 1979), and Carvacho (1989) suggested that the genus had a primarily North Pacific Ocean origin and subsequently dispersed throughout the Pacific Ocean by following the continental shelves; to New Zealand via Antarctica; and to the Atlantic Ocean by crossing the Arctic polar ocean. Newman (1991) suggested that Cancer s. $l$. displayed a relict amphitropical distribution in the temperate North Pacific and South Pacific Oceans. This conclusion was based on the belief that Cancer $s . l$. was the sole extant genus of the family. The extinction of several tropical to subtropical genera in the Eocene to Miocene was cited as evidence that the genus, and by implication, the family, arose and subsequently became extinct in the tropics, resulting in a formerly Tethyan distribution for Cancer s. $l$. and the family. However, this hypothesis is no longer tenable for several reasons. The genus Cancer sensu Newman has been redefined; for example, Newman (1991) considered species of all four of the former subgenera of Cancer as well as members of the genus Platepistoma in his discussion of the genus. The redefinition of these genera results in a very different distributional pattern for Cancer s. s. as well as the four additional genera Newman (1991) considered as members of Cancer s. $\boldsymbol{l}$. Furthermore, Newman (1991) cited the appearance and extinction of Parapirimela in the Miocene of Angola as evidence of a formerly tropical distribution of the Cancridae. However, that genus is probably not a member of the family, and in any case, its familial placement cannot be verified. The revision of each of the genera 
within the Cancridae makes it possible in this report to recast the biogeographic history of the family, the two included subfamilies, and each genus (generic discussions above).

The earliest known confirmed occurrences of the family are Lobocarcinus of the Lobocarcininae from the middle Eocene of Egypt and Notocarcinus of the Cancrinae from the middle Eocene of South America. Anisospinos is known from late Eocene rocks of Washington, and Metacarcinus makes its first appearance in Oligocene (?) rocks of Alaska. Several genera make their first appearance in the Miocene, including Cancer s. s. from Japan, Anatolikos from Japan, Platepistoma from Japan, Romaleon from Japan and California, Miocyclus from Bulgaria, and Tasadia from Romania and Belgium; the latter two genera are members of the Lobocarcininae and the rest are members of the Cancrinae. It is difficult to determine when and where the family first appeared because the earliest known occurrences from Eocene rocks are known from each of the two subfamilies. This suggests that the family arose sometime before the middle Eocene. However, further speculation upon exactly when and where this occurred is unwarranted until more fossil material is recovered.

Several patterns emerge from these occurrences. Clearly, the two subfamilies have had very different evolutionary and dispersal histories. The Lobocarcininae has a primarily Tethyan distribution, as has already been discussed above, since all but one species of one genus are known from the Tethys region. The Cancrinae appear to have evolved in the southern hemisphere, based upon the occurrence of Notocarcinus in the middle Eocene of Argentina, and subsequently dispersed northward along the coast into the North Pacific Ocean. All other genera referred to the Cancrinae have their earliest recorded occurrence in the North Pacific region. Several genera within the Cancrinae are endemic to the North Pacific Ocean, including Anatolikos, Anisospinos, and Glebocarcinus. Platepistoma is known only from the Indo-Pacific region. Cancer s. $s_{x}$ and Metacarcinus range throughout the North Pacific Ocean, into the southeastern Pacific, and into the North Atlantic Ocean. One species of Metacarcinus is known from New Zealand. Romaleon is known from the circum-North Pacific
Ocean, with one species ranging into the southeastern Pacific region. These distributions suggest that the North Pacific Ocean is the area of origin and subsequent dispersal for almost all of the cancrine genera.

\section{Acknowledgements}

The specimens of Anisospinos berglundi were collected and donated by R. E. Berglund, Baìnbridge Island, Washington. Specimens of Metacarcinus goederti were collected by $\mathrm{L}$. Marincovich and donated by Charles $\mathrm{L}$. Powell II, both of the United States Geological Survey, Menlo Park, CA. Locality information for $M$. goederti was supplied by Powell. The holotypes of Anisospinos wahkiakumensis and Metacarcinus starri were kindly loaned by R. Eng, Thomas Burke Memorial Washington State Museum, Seattle. The holotypes of Branchiolambrus altus and several cancrid taxa were graciously loaned by W. Blow, United States National Museum of Natural History, Washington, D.C.F. Collier, Museum of Comparative Zoology, Harvard University, Boston, MA, loaned the holotype of Cancer proavitus. H. Kato, Natural History Museum and Institute, Chiba, Japan, and H. Karasawa, Mizunami Fossil Museum, Mizunami, Japan, provided helpful discussions about Japanese cancrids and provided access to specimens of the Japanese taxa discussed here at their respective institutions. The manuscript was greatly improved by the thoughtful reviews of Joe $\mathrm{S} . \mathrm{H}$. Collins, London, England, and the late Austin B. Williams, United States National Museum of Natural History, Washington, D.C. Travel to examine Japanese fossil material was funded by National Geographic Society Grant 6265-98 to Feldmann and Schweitzer. Travel and field work to collect Argentinian material was funded by National Geographic Society Grant 5588-95 to Feldmann.

\section{References}

Anderson JL, Feldmann RM. 1995. Lobocarcinus lumacopius (Decapoda: Cancridae), a new species of cancrìd crab from the Eocene of Fayum, Egypt. J. Paleontol. 69: 922-932.

Balss H. 1922. Diagnosen neuer japanischer Decapoden, Zool. Anz. 54: 1-6.

Bell T. 1835. Observations on the genus Cancer of Dr. Leach (Platycarcinus, Latr.), with descriptions of three new species. Proc. Zool. Soc. London 3: 86-88.

Berglund RE, Goedert JL. 1996. A new crab (Brachyura: Cancridae) from lower Miocene rocks of the northwestern Olympic Peninsula, Washington. J. Paleontol. 70: 830835.

Berglund RE, Goedert JL. 1992. A new species of Cancer (Decapodax Brachyura) from the Miocene Astoria Formation in Washington. Burke Museum Contrib, Anthropol. Nat. Hist. 9: 11 p. 
Berthold AA. 1827. Latreille's Naturlíche Familien des Thíerreíchs. Aus dem Französisschen mit Anmerkungen und Zusătzen, 606 pp.

Beurlen K. 1930. Vergleîchende Stammesgeschìchte Grundlagen, Methoden, Problemè unter besonderer Berŭcksíchtígung der höheren Krebse. Fortsch. Geol. Palaeontol. 8: 540-546.

Beurlen K. 1958. Contribuị̂ão a paleontología do Estado do Pará, Crostaceos decấpodos da Formação Pírabas, Boletimo Museum Paraense Emilio Goeldi, N. S. (Geol.) 5: 248.

Bíttner A. 1883. Neue Beitrẫge zur Kenntnis tertiårer Brachyuren Faunen. I. Brachyuren des Alttertiârs von Verona. Denkschrift Akademie Wissenschaften, Wien 48: 15-30.

Bittner A. 1893. Decapoden des pannonischen Tertiärs. Sitzungsber. Denkschrift Akademie die Wissenschaften Wien 102: 44-55.

Bonfiglio L, Donadeo G. 1982. Cancer sismondai Meyer nel Plíocene dî Torre Dell'Orso (Puglia), Att. Soc. Ital. Sc. Nat. Mus. Civ. Stor, Nat, Milano 123: 255-296.

Carvacho A. 1989. Cancer johngarthi, n. sp. and Cancer porteri (Bell) (Crustacea: Decapoda): comparisons and hypothesis. Proc. Biol. Soc. Wash. 102: 613-619.

Casadio S, Feldmann RM, Foland KA. ${ }^{40} \mathrm{Ar} /{ }^{39} \mathrm{Ar}$ age and oxygen isotope temperature of the Centinela Formation, southwestern Argentina: An Eocene age for crustaceanrich "Patagonian" beds, J. S. Amer. Geol. 13: 123-132.

Collins JSH, Barber AJ. 1998. A new middle Eocene crab, Lobocarcinus pentanodosus sp. nov. (Crustacea, Decapoda) from Doi Doi, Barru, South Sulawesi, Indonesia. Bull. Mizunami Fossil Museum 25: 97-101.

Collins JSH, Fraaye RHB. 1991. Cancer parvidens, a new crab (Crustacea, Decapoda) from the Miocene of the Netherlands. Contrib. Tertiary and Quaternary Geology 28: 1-7.

Crosnier A. 1976. Doneếs sur les crustacès décapodes capturěs par M. Paul Guézé à l'île de La Réunion lors d'essaís de pêche en eau profonde. In: Biologie marine et exploitation des ressources de l'océan Indien occidental. Colloque Commerson, La Réuníon 16-24 octobre 1973. Trav, Doc. ORSTOM 47: 225-256.

Dana JD. 1852. Conspectus Crustaceorum, \& c. Conspectus of the Crustacea of the Exploring Expedition under Capt. Wilkes, U.S.N., including the Crustacea Cancrodiea Corystoidea. Proc. Acad. Nat. Scí. Philadelphía 6: 73-86.

Davie PJF. 1991. Crustacea Decapoda: The genus Platepistoma Rathbun, 1906 (Cancridae) with the description of three new species. Mém.Mus. Nat. Hist. Nat. (A) 152: 493-514.

Ekman S. 1953. Zoogeography of the Sea. London: Sidgwick and Jackson.

Fabricius JC. 1775. Systema entomologiae, sistens insectorum classes, ordines, genera, species adiectis synonymis, locis, descriptionibus, observationibus. Flensburgi and Lipsiae

Feldmann RM, Fordyce RE. 1996. A new cancrid crab from New Zealand. New Zealand J. Geol. Geoph. 39; 509-513.

Gistl JNFX von. 1848. Naturgeschichte des Thierreichs fur
Höhere Schulen. Stuttgart: Hoffman'scherlags-Buchhandlung.

Glaessner MF. 1929. Crustacea Decapoda. In: Pompecki JF, ed. Fossilium Catalogus Animalia, part 41. Berlin.

Glaessner MF. 1933. New Tertiary crabs in the collection of the British Museum. Ann Mag. Nat. Hist. 27: 13-26.

Glaessner MF. 1969. Decapoda. In: Moore RC, ed. Treatise on invertebrate paleontology, part $R$, Arthropoda 4. Lawrence: Univ. Kansas Press, 400-651.

Gripp K. 1969. Fossilien aus Norddeutschland. Meyniana 19: $79-89$.

Guinot D. 1977. Propositions pour une nouvelle classification des Crustacés Décapodes Brachyoures. C. R. Acad Sci. Paris, serie D 285: 1049-1052.

Haan W de. 1833-1849. Crustacea. In: Von Siebold PF, ed. Fauna Japonica sive Descriptio animalium, quae in itinere per Japoniam, jussu et auspiciis superiorum, qui summum in India Batava Imperium tenent, suscepto, annis 1823-1830 collegit, notia, observationibus et adumbratilonibus illustravit, 4, 17, 31. Leiden; J. Muller, 109-164.

Imaizumi R. 1962. Miocene Cancer (Brachyura) of Japan. Scientific Reports, Tohoku University, Sendai, Japan, Second Series (Geology), Special Volume 5: 233-247, pl. 40.

Jacquuìnot H, Lucas H. 1853. "Voyage ua Pole Sud et dans l'Oceanie surr les Corvettes L'Astrolabe et la Zelee. Zoologie 3, Crustaces. Paris: Gide et Baudry.

Janssen AJ, Müller P. 1984. Miocene Decapoda and Mollusca from Ramsel (province of Antwerpen, Belgium), with a new crab genus and a new cephalopod species. Scripta Geologica 75: 1-26.

Johnson JY. 1861. Description of a new species of Cancer obtained at Madeira. Proc. Zool. Soc. London 16: 240" 242.

Karasawa H. 1990. Decapod crustaceans from the Miocene Mizunami Group, Central Japan. Part 2. Section Oxyryncha, Cancridea, and Brachyryncha. Bull. Mizunami Fossil Museum 17: 1-34.

Karasawa H. 1993. Cenozoic decapod Crustacea from southwest Japan. Bull. Mizunami Fossil Museum 20: 1-92.

Karasawa H. 1997. A monograph of Cenozoìc stomatopod, decapod, isopod and amphipod Crustacea from west Japan. Monograph of the Mizunami Fossil Museum, No. 8: 81.

Kato H. 1996. Miocene decapod crustaceans from the Chichibu Basin, Central Japan. Trans. Proc. Palaeontol. Soc. Japan, $N \times S .183$ : 500-521.

Latreille PA. 1802-1803. Histoire naturelle, générale et particulière, des crustacés et des insectes. Volume 3. Paris: F. Dufart.

Linnaeus C. 1758. Systema naturae per regna tria naturae, secundum classes, ordines, genera, species, cum characteribus, differentiis, synonymis, locis, ed. 10, 1 .

Lörenthey I. 1897. Adatok Magyarorszấg harmadkorù rảkfaunájẩhoz. Mathematikai ès Természettudományi Êrtesitö 15: 149-169.

Lỗrenthey I. 1909. Beîtrầge zur Kenntnis der eozẫnen Decapodenfauna Aegyptens. Math-Naturw. Ber, a. Ungarn. 25: 106-152, pls. 1-2. 
Lörenthey I, Beurlen K. 1929. Die fossilen Dekapoden der Lânder der ungarische Krone. Geologica Hungarica, Series Palaeontologica, Fasciculus 3.

Meigen JW. 1803. Klassifikazion und beschreibung der europäischen zweiflügligen insekten (Diptera Linn.). Magazine fur Insekten Kunde (Illiger) 2: 258-265, pl.XIII.

Meyer H von. 1843. Brieflïche Mittheilungen an Prof. Bronn. gerichtet. Neues Jahrb. Mineral. Geolog. Pal. Stutgard, 579-590.

Meyer H von. 1847. Cancer Paulino-Würtemburgensis a. einem jüngeren Kalkst. in Aegypten. Palaeontographica 1: 91 , pl. 1, figs. 1-7.

Miers EJ. 1879. On a collection of Crustacea made by Capt. H. D. St. John, R. N., in the Corean and Japanese Seas. Part 1. Podophthalmia. Proc. Zool. Soc. London 18.

Milne Edwards A. 1861-1865. Histoíre des Crustacés podophthalmaires fossiles. Paris: Victor Masson.

Milne Edwards A. 1862. Monographie des Crustacés Fossiles de la Famille des Canceriens. Annales de la Science Naturelle 18: 31-85.

Milne Edwards H. 1834-1840. Histoire naturelle des Crustacés, comprenant 1'anatomie, la physiologie, et la classification de ces animaux. 1,$1834 ; 2,1837 ; 3,1840$; atlas.

Müller, P. 1979. Crustacés Décapodes du Baděníen et Sarmatien de Bulgarie. Palaeontology, Stratigraphy, and Lithology. Bulgarian Academy of Sciences 10: 3-8.

Múller P. 1984. Decapod Crustacea of the Badenian. Geologica Hungarica, Series Palaeontologica 42.

Nagao T. 1941. On some fossil crustacea from Japan. $J$. Fac. Sci. Hokkaido Univ. ser, VI 6: 85-97.

Nations JD. 1975. The genus Cancer (Crustacea: Brachyura): systematics, biogeography, and fossil record. Natural History Museum of Los Angeles County Science Bulletin 23: $1-104$.

Nations JD. 1979. The genus Cancer and its distribution in tìme and space. Bull. Biol. Soc. Wash. 3:153-187.

Newman WA. 1991. Origins of southern hemisphere endemism, especially among marine Crustacea. Mem. Queensland Museum 31: 51-76.

Ortmann AE. 1893. Die Dekapoden-Krebse des Strassbyrger Museums. VII. Theil. Abthheilung: Brachyura (Brachyura genuina Boas) II. Unterabtheilung: Cancroidea, 2. Section: Cancrinea, 1. Gruppe: Cyclometopa. Zoologischen Jahrbüchern. Abtheilung fur Systematik, Geographile, und Biologie der Thiere 7: 411-495.

Packard AS. 1900. A partial phylogeny of the genus Cancer. Proc. Am. Ass. Adv. Sci. 49: 239-240.

Poeppig EF. 1836. Crustacea Chilensia. Archiv für Naturgeschichte 2: 133-145, pl. IV.

Quenstedt FA. 1867. Handbuch der Petrefaktenkunde. Tübingen, $1852: 265-274$, pls. $x x$, xxi; ed. 2, 1867; ed. 3 , 1882-85: 406-420, pls. xxxîi-xxxîî.

Randall JW. 1839. Catalogue of the Crustacea brought by Thomas Nuttall and J. K Townsend, from the West Coast of North America and the Sandwich Islands, with Descriptions of such Species as are apparently new, among which are included several species of different localities, previously existing in the collection of the Academy. $J_{*}$ Acad. Nat. Sci. Philadelphia 8: 106-147, pls. 3-7.

Rathbun MJ. 1897. Description of a new species of Cancer from Lower California, and additional note on Sesarma. Proc. Biol. Soc. Wash. 11: 111-112.

Rathbun MJ. 1898. The Brachyura collected by the U.S. Fish Commission Steamer Albatross on the voyage from Norfolk, Virginia to San Francisco, Calífornìa, 1887-1888. Proc. U.S. Nat. Mus. 21: 567-616.

Rathbun MJ. 1900. Synopses of North-American Invertebrates. VII. The Cyclometopous or Cancroid crabs of North America. The American Naturalist 34: 131-143.

Rathbun MJ. 1906. The Brachyura and Macrura of the Hawailian Islands. Bull. U.S. Fish Comm. Washington 23: 827-930.

Rathbun MJ. 1908. Fossils crabs from California. Proc U.S. Nat. Mus, 35: 341-349.

Rathbun MJ. 1917. Description of a new crab from the California Pliocene Proc, U.S. Nat. Mus. 53: 451-452.

Rathbun MJ. 1926. The fossil stalk-eyed Crustacea of the Pacific Slope of North America. U.S. Nat. Mus. Bull. 138: 1-155.

Rathbun MJ. 1930. The cancroild crabs of America of the families Euryalidae, Portunidae, Atelecyclidae, Cancridae, and Xanthidae. U.S. Nat. Mus. Bull. 152: 1-609

Rathbun MJ. 1932. A new species of Cancer from the Pliocene of the Los Angeles basin, J. Wash. Acad. Sci. 22: $19-20$.

Reuss AE. 1867. Die fossile Fauna der Steinsalzanlagerung von Wieliczka in Galizien. Sitzungsber. Math. Naturwiss. Cl. Akad. Wissenschaften, Wien. Abt. I. 40: 173-176, pl. 8.

Sakai T. 1969. Two new genera and twenty-two new species of crabs from Japan. Proc. Biol. Soc. Wash. 82: 243-280.

Sakai T. 1976. Crabs of Japan and the Adjacent Seas. Tokyo, Kodansha LTD, 1-773.

Sakumoto T, Karasawa H, Takayasu K. 1992. Decapod crustaceans from the Middle Miocene Izumo Group, Southwest Japan. Bull. Mizunami Fossil Museum 19: 441-453.

Say T. 1817-1818. An account of the Crustacea of the United States. J. Acad. Nat. Sci. Philadelphia 1(1)(1817):57-63, $65-80,97-101,155-169 ;(2)(1818) \times 235-253,313-319,374-$ $401,423-444,445-458$, pl. 4.

Stimpson W. 1854-1857. On some Californian Crustacea. Proc. Calif. Acad. Nat. Sci. 2nd ed. 1: 1-88.

Stimpson W. 1859. Notes on North American Crustacea, No. I. Ann. Lys, Nat. Hist. New York 7: 49-93.

Straelen V van. 1937. Parapirimela angolensis brachyure nouveau du Míocène de l'Angola, Bull. Mus. Roy.d'Hist. Nat. Belgique 8: 1-4.

Takeda M. 1977. Two interesting crabs from Hawaii. $P a-$ cific Science 31: 31-38.

Toula F. 1904. Ueber eíne neue Krabbe aus dem mỉozânnen Sandstein von Kalksburg b. Wien. Jahrbuch der Kais. Kon. Geologischen Reichs-Anstalt 54: 161-168. 
Weber F. 1795. Nomenclator entomologícus secundum entomologiam systematicum ill. Fabricii, adjectis speciebus recens detectis et varietatibus. Chilonii (Kiel) et Hanburgi, 1-171.

Williams AB. 1984.' Shrimps, Lobsters, and Crabs of the Atlantic Coast of the Eastern United States. Washington: Smithsonian Institution Press, 1-550.

Yokoya Y. 1933. On the distribution of Decapod Crustaceans inhabiting the Continental Shelf around Japan, based upon the Materials collected by S. S. Soyo-Maru, during the years 1923-1930, J. Coll. Agriculture Tokyo Imperial University 12: 1-226.

Zarenkov NA. 1990. Decapods (Stenopodidea, Brachyura, Anomura) of the Nacza and Sala-y-Gomez underwater ridges. Trans. P. P. Shorshov Inst. Oceanol. Ac. Sci. USSR 124: 218-244.

Accepted: 5 June 2000

APPENDIX A: Systematic list of all species and genera currently assigned to the Cancridae. Species included in each genus are listed after the genus.

\section{Family Cancridae, Subfamily Cancrinae}

Genus Cancer sensu stricto: Cancer bellianus Johnson, 1861; C. borealis Stimpson, 1859; C. fissus Rathbun, 1908; C. fujinaensis Sakumoto, Karasawa, and Takayasu, 1992; $C$. irroratus Say, 1817; C. johngarthi Carvacho, 1989; $C$. pagurus, Linnaeus, 1758; C. parvidens Collins and Fraaye, 1991; C. porteri Rathbun, 1930; C. plebejus Poeppig, 1836; C. productus Randall, 1839.

Genus Anatolikos: Anatolikos japonicus (Ortmann, 1893) new comb., as Cancer, A. itoigawai (Karasawa, 1990) new comb., as Cancer (Glebocarcinus); and A. tumifrons (Yokoya, 1933) new comb., as Cancer.

Genus Anisospinos: Anisospinos berglundi new species; Anisospinos odosensis (Imaizumi, 1962), new comb., as Cancer; and A. wahkiakumensis (Berglund and Goedert, 1992) new comb., as Cancer (Romaleon).

Genus Glebocarcinus: Glebocarcinus amphioetus (Rathbun, 1898), as Cancer and $G_{\times}$oregonensis (Rathbun, 1898), as Cancer.

Genus Metacarcinus: Metacarcinus anthonyi (Rathbun, 1897) as Cancer, $M_{\times}$danai Nations, 1975, as Cancer (Metacarcinus); M. davidi Nations, 1975, as Cancer (Metacarcinus); $M$. edwardsii (Bell, 1835), as Cancer, M. gracilis (Dana, 1852), as Cancer; M. granti (Rathbun, 1932), as Cancer; M. izumoensis Sakumoto, Karasawa, and Takayasu, 1992, as Cancer (Metacarcinus); M. jenniferae Nations, 1975, as Cancer (Metacarcinus); M. magister (Dana, 1852), as Cancer, M. minutoserratus (Nagao, 1941), as Cancer; M. novaezealandiae (Jacquinot, 1853), as Cancer; $M$. starri Berglund and Goedert, 1996, as Cancer (Metacarcinus).

Genus Notocarcinus: Notocarcinus sulcatus new species. -

Genus Platepistoma: Platepistoma anaglyptum Balss, 1922; $P$. guezi (Crosnier, 1976), as Cancer, P. imamurae (Imaizumi,
1962), as Cancer; $P$. kaedei (Karasawa, 1990) new comb., as Cancer (Glebocarcinus); P. kiribatiense Davie, 1991; Platepistoma macrophthalmous Rathbun, 1906; $P$. nanum Davie, 1991; P. balssi (Zarenkov, 1990), as Cancer; $P$. seychellense Davie, 1991.

Genus Romaleon: Romaleon antennarius (Stimpson, 1856), as Cancer, $R$. branneri (Rathbun, 1926), as Cancer, $R$, dereki Nations, 1975, as Cancer (Romaleon); $R$. gibbosulus (Rathbun, 1898), as Cancer; $R$.jordani (Rathbun, 1900), as Cancer; $R$. nadaensis (Sakai, 1969) new comb., as Cancer, $R$. polyodon (Poeppig, 1836), as Cancer; $R$, sakamotoi (Kato, 1996) new comb., as Cancer; $R$, sanbonsugii (Imaĩzumi, 1962), new comb., as Cancer; R. urbanus (Rathbun, 1917), as Cancer.

II. Family Cancrìdae, Subfamily Lobocarcininae

Genus Lobocarcinus: Lobocarcinus aegypticus Lörenthey, 1909; L. indicus Glaessner, 1933; L. lumacopius Anderson and Feldmann, 1995; L. paulinowuerttemburgensis von Meyer, 1847; L. pustulosus Feldmann and Fordyce, 1996; L. sismondai von Meyer, 1843, new comb., as Cancer.

Genus Miocyclus: Miocyclus bulgaricus Mũller, 1979

Genus Tasadia: Tasadia carniolica (Bittner, 1884), as Cancer.

\section{APPENDIX B: Key to the Genera of the Cancridae.}

1. Carapace with odd number of frontal spines; posterolateral margin smooth or with one or two small spines

Cancrinae and 2

1'. Carapace with even number of frontal spines; posterolateral margin with numerous coarse granules or spines

Lobocarcininae and 9

2. Carapace regions separated by very deep, narrow, smooth grooves; surface of regions densely granular; anterolateral spines small, wider than high Platepistoma

2 . Carapace regions separated by weak grooves or indistinct; carapace region ornamentation variable but not as above; anterolateral spines typically better developed, longer $\ldots . . . . . .3$

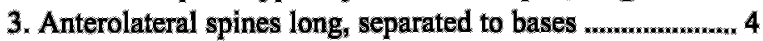
3. Anterolateral spines predominantly fissured or separated to base and short, granular, or serrate

4. Carapace not much wider than long; regions distinet, separated by wide, smooth, grooves; regions densely granular on most elevatedportion ............................................... Glecarcinus 4. Carapace much wider than long; regions separated by narrow grooves or indistinct; regional ornamentation variable $\ldots . . m \times n .5$ 5. Anterolateral spines singular, curving anteriorly

\section{Romaleon}

5x. Anteròlateral spines mostly paíred, curving anteriorly, each of different size. Anisospinos 6. Front weakly projected, orbits directed forward, spines distinct

6. Front strongly projected, frontal spines coalesced; orbits anterolaterally directed

7. Anterolateral spines predominantly strongly fissured, may be separated to base posteriorly. Cancer

7. Anterolateral spines less distinctly fissured or small, separated 
to bases, terminations granular or serrate ........... Metacarcinus 8. Anterolateral spines mostly paired, terminations sharp, regions inflated 8. Anterolateral spines singular, terminations blunt, epigastríc and hepatíc regions sulcate. Notocarcinus 9. Frontal margin with six spines; anterolateral spines fissured, with blunt terminations except for ninth which is sharp; posterolateral margin smooth Miocyclus
9'. Frontal margin with four to six spines; anterolateral spines sharp, separated to bases, often bifurcate or trifurcate; posterolateral margin with large granules or spines ......................... 10 10. Anterolateral spines obviously bifurcate or trifurcate; posterolateral margin with prominent spines ..... Lobocarcinus 10'. Anterolateral spines singular or weakly bifurcate; posterolateral margin with coarse granules .................. Tasadia 